\title{
Exosomes: Cell-Derived Nanoplatforms for the Delivery of Cancer Therapeutics
}

\author{
Hyosuk Kim ${ }^{1,+}$, Eun Hye Kim ${ }^{1,2, \dagger}$, Gijung Kwak ${ }^{1,3}$, Sung-Gil Chi ${ }^{2}{ }^{\oplus}$, Sun Hwa Kim ${ }^{1, *}$ and Yoosoo Yang ${ }^{1, *}$ \\ 1 Center for Theragnosis, Biomedical Research Institute, Korea Institute of Science and Technology (KIST), \\ Seoul 02792, Korea; hyoseog7@kist.re.kr (H.K.); ehkelly@kist.re.kr (E.H.K.); kwakgijung@gmail.com (G.K.) \\ 2 Department of Life Sciences, Korea University, Seoul 02841, Korea; chi6302@korea.ac.kr \\ 3 Department of Ophthalmology, Johns Hopkins University School of Medicine, Baltimore, MD 21231, USA \\ * Correspondence: sunkim@kist.re.kr (S.H.K.); ysyang@kist.re.kr (Y.Y.); \\ Tel.: +82-02-958-6639 (S.H.K.); +82-02-958-6655 (Y.Y.) \\ + These authors contributed equally to this work.
}

Citation: Kim, H.; Kim, E.H.; Kwak, G.; Chi, S.; Kim, S.H.; Yang, Y. Exosomes: Cell-Derived Nanoplatforms for the Delivery of Cancer Therapeutics. Int. J. Mol. Sci. 2021, 22, 14. https://dx.doi.org/10.3390/ ijms22010014

Received: 27 November 2020 Accepted: 18 December 2020 Published: 22 December 2020

Publisher's Note: MDPI stays neutral with regard to jurisdictional claims in published maps and institutional affiliations.

Copyright: $\odot 2020$ by the authors. Licensee MDPI, Basel, Switzerland. This article is an open access article distributed under the terms and conditions of the Creative Commons Attribution (CC BY) license (https://creativecommons.org/ licenses/by/4.0/).

\begin{abstract}
Exosomes are cell-secreted nanovesicles that naturally contain biomolecular cargoes such as lipids, proteins, and nucleic acids. Exosomes mediate intercellular communication, enabling the transfer biological signals from the donor cells to the recipient cells. Recently, exosomes are emerging as promising drug delivery vehicles due to their strong stability in blood circulation, high biocompatibility, low immunogenicity, and natural targeting ability. In particular, exosomes derived from specific types of cells can carry endogenous signaling molecules with therapeutic potential for cancer treatment, thus presenting a significant impact on targeted drug delivery and therapy. Furthermore, exosomes can be engineered to display targeting moieties on their surface or to load additional therapeutic agents. Therefore, a comprehensive understanding of exosome biogenesis and the development of efficient exosome engineering techniques will provide new avenues to establish convincing clinical therapeutic strategies based on exosomes. This review focuses on the therapeutic applications of exosomes derived from various cells and the exosome engineering technologies that enable the accurate delivery of various types of cargoes to target cells for cancer therapy.
\end{abstract}

Keywords: extracellular vesicle; exosome; cancer therapeutic; drug delivery; exosome engineering

\section{Introduction}

Extracellular vesicles (EV) are one of the means of intercellular communication between adjacent and distant cells. EVs refer to all membrane vesicles that are naturally released from cells and are classified based on their biogenesis pathway, function, size, etc. [1]. EVs are commonly composed of three members: (i) apoptotic bodies released by the cell undergoing programmed cell death, with size ranging from 500 to $1000 \mathrm{~nm}$, (ii) microvesicles emerging from the budding of plasma membranes with a diameter of 150-500 nm, and (iii) exosomes with a diameter of 40-150 nm that are derived from endosomes (Figure 1) [2].

Among them, exosomes play essential roles as communication mediators between cells and contain many important biomolecules such as proteins, nucleic acids, and lipids [3]. These cargoes of exosomes vary depending on the origin of exosomes and their biological state. More recently, exosomes have been known to mediate many physiological and pathological processes by presenting various antigens through the interactions of receptorligand between exosomes and the cell membrane, releasing cargo through internalizing into targeted cells, or delivering their surface proteins through membrane fusion [4-6]. Due to the discovery of these roles of exosomes, they have recently received the most research attention as a promising drug delivery tool that can overcome the shortcomings of artificial nanoparticles. 
The hurdles of some artificial nanoparticles, such as immune recognition [7], inflammatory toxicity [8], and rapid clearance [9], can be overcome due to the biochemical composition of exosomes similar to the cell membrane of exosomes. In contrast to artificial nanoparticles, exosomes have relatively low immune clearance and low cytotoxicity due to their endogenous origin and high biocompatibility. Furthermore, exosomes are capable of delivering both hydrophilic and hydrophobic molecules, and they have efficient target homing abilities to tumor sites that are potentially attributed to their multivalent display of cell-derived surface moieties [10,11].

In this review, we aim to provide a comprehensive understanding of exosomes, including their biogenesis, function, therapeutic applications for cancer treatment, as well as various engineering techniques in drug delivery.

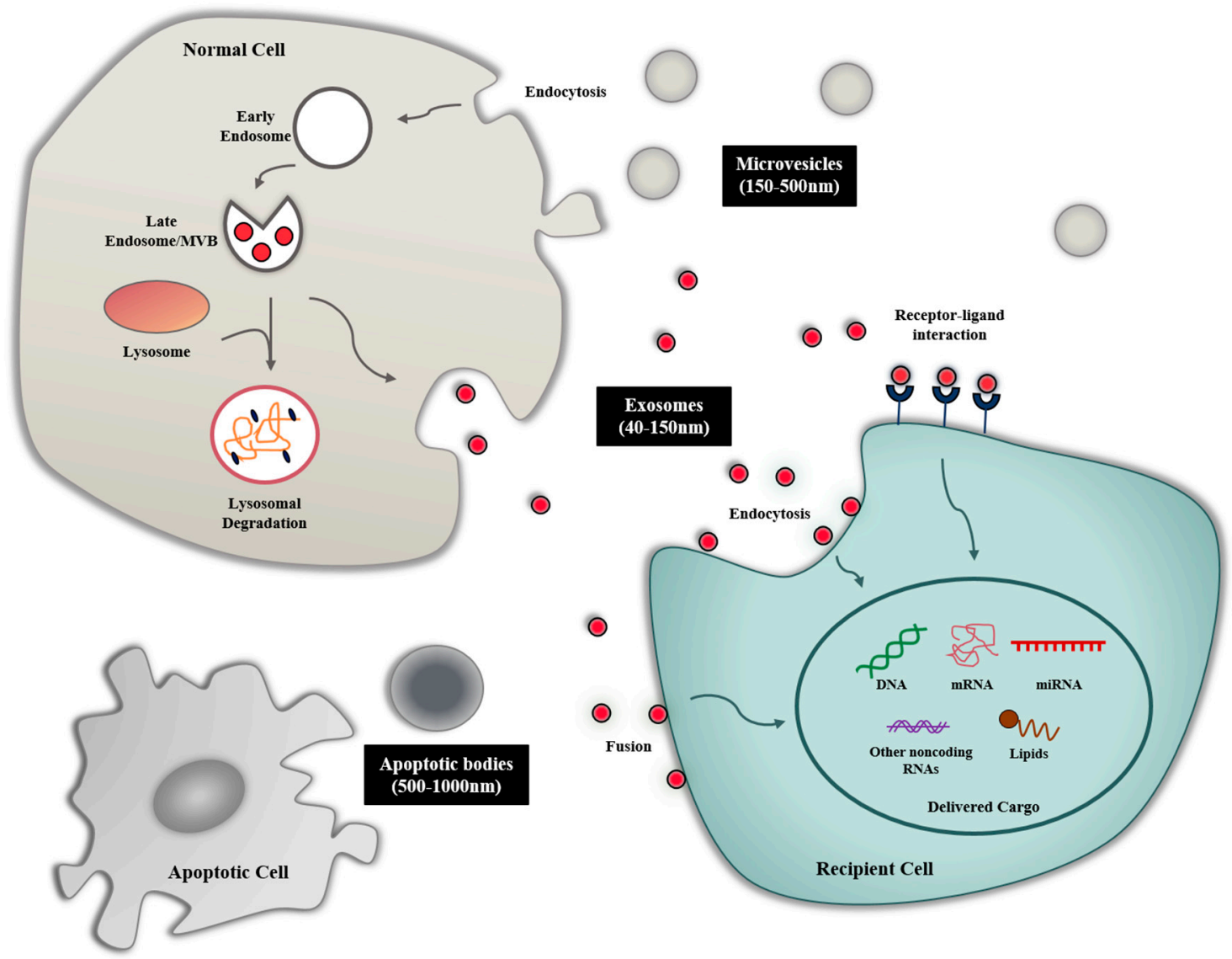

Figure 1. Biogenesis and uptake mechanisms of exosomes. Early endosomes generated through invagination of the plasma membrane form multivesicular bodies (MVB) through inward budding, which releases exosomes through the exocytosis. Released exosomes can be taken up via different mechanisms: endocytosis, membrane fusion, receptor-ligand interaction.

\section{Biogenesis and Composition of Exosomes}

\subsection{Biogenesis of Exosome}

The exosome is a small vesicle of endocytic origin with a diameter of $40-150 \mathrm{~nm}$ and contains many types of biomolecules such as proteins and nucleic acids [2]. The biogenesis of exosomes is a complex biological process that has yet to be fully elucidated. First, the biogenesis of exosomes is primarily initiated in the endocytosis process in the lipid raft domain of the plasma membrane. The intracellular early endosomes are generated by the inward budding of the plasma membrane, and these early endosomes become the late endosome with the assistance of the Golgi complex. During this process, intraluminal vesicles (ILVs), which we refer to as exosomes, are formed in the late endosomes through 
the endosomal sorting complexes required for transport (ESCRT)-dependent and ESCRTindependent mechanisms. Various biomolecules within the cells can be accumulated during the inward budding of the endosomal membrane that form multivesicular bodies (MVBs) [12]. Finally, most of the MVBs fuse with the plasma membrane of the cells, and ILVs are released to extracellular environment by exocytosis. MVBs that are not fused to the plasma membrane are degraded by lysosomes. The process by which MVB docks to the plasma membrane is known to be regulated by Rab GTPase [13]. In addition to ILVs, recent studies have reported that small-sized microvesicles (around $150 \mathrm{~nm}$ ) budding from the plasma membrane can also be included in exosomes members [14].

\subsection{Exosome Composition}

Even exosomes derived from the same cell are heterogeneous in their size and cargo. However, some cargoes are partially common in exosomes derived from various origins. [15]. According to various exosome studies, exosomes contain numerous biomolecules such as lipids, proteins, RNAs, and DNAs. Most lipids in exosomes are known to be components of the plasma membranes such as cholesterol, sphingomyelin, and phosphatidylserine [16]. The proteome of exosomes include proteins involved in membrane transport or fusion (Rab GTPases, annexins), proteins associated with exosome biogenesis (ESCRT complex, Alix, TSG101), heat shock proteins (HSP70, HSP90), integrins, tetraspanins (CD63, CD81, CD82) [12,16,17], myosin heavy chain (MHC) class II proteins, etc. [18]. In addition, there are many proteins that are expressed on the surface of exosomes and interact with surface receptors of recipient cells to induce intracellular signaling. All RNA species, such as microRNA (miRNA) and messenger RNA (mRNA) as well as transfer RNA and long noncoding RNA, have been identified in exosomes $[19,20]$. In many studies, it has been reported that specific RNAs are actively, not passively, sorted and carried into exosomes and subsequently affect the transcriptome of recipient cells [3,21]. Interestingly, Batagov et al. also found that the 3 -untransrated region (UTR) of mRNA could enter the exosome via a specific RNA fragment [22]. In addition, Balaj et al. identified single-stranded DNA in the exosome [23], and Kalluri and coworkers provided the evidence that exosomes contain double-stranded genomic DNA fragments of $10 \mathrm{~kb}$ or more using whole genome sequencing [24].

\section{Exosome-Mediated Intercellular Communication}

\subsection{Exosome Uptake}

According to current studies, the mechanism by which exosome signals are transferred to recipient cells can be largely defined in three methods: receptor interaction, direct membrane fusion, and endocytosis/phagocytosis. For example, Cosseti et al. found that interferon- $\gamma$ (IFN- $\gamma$ ) binds to exosome-associated IFN- $\gamma$ receptor 1 to form a complex, which in turn activates signaling transduction through this complex in neural stem/precursor cells [4]. In addition, some studies have suggested that exosomes transfer their contents to target cells by fusion with a membrane of recipient cells, but the exact molecular mechanism has not been elucidated [6]. Recently, many studies suggest that internalization via endocytic pathways, such as clathrin-mediated endocytosis, lipid raft-mediated endocytosis, macropinocytosis, caveolin-mediated endocytosis, and phagocytosis, is the main method of exosome uptake [5]. These findings suggest that exosome uptake is cell-specific by the interaction of surface molecules between specific cells and exosomes.

\subsection{Exosome-Mediated Intercellular Communication in Tumor Microenvironment}

Exosomes play crucial roles in intercellular communication by delivering biomolecules. Exosome-derived biomolecules secreted by donor cells could effectively change the biological response of recipient cells. Zhang et al. found that the exosome with a significant amount of miRNA-150 secreted by human monocytic leukemia cell line (THP-1) could contribute to target cell migration through the inhibition of target gene expression [25]. 
In another study, Wang et al. demonstrated that the exosome-mediated delivery of transient receptor potential polycystic 2 (TRPP2) siRNA significantly inhibits TRPP2 expression and the epithelial-mesenchymal transition of FaDu cells [26]. Several studies also proved that exosomes containing functional proteins can mediate cell-to-cell communication and have critical effects on the signaling pathway of the target cell, which is related with cancer progression [27]. Therefore, exosome-mediated cell-to-cell interaction is an effective way to deliver diverse cellular biomolecules and affect functions and phenotypes of target cells.

In our body, natural-killer (NK) cells are responsible for immune surveillance and serve as the first-line defense in regulating cancer growth and metastasis. NK cell-derived exosomes endow cytotoxic activity to tumor cells by carrying killer proteins together with typical NK and exosome markers [28].

Similar to NK cells, macrophages play an important role in innate host defense and in killing tumor cells by producing reactive oxygen/nitrogen species and pro-inflammatory cytokines such as tumor necrosis factor-alpha (TNF- $\alpha$ ) and interleukin 6 (IL-6). Macrophages are broadly classified into M1 or M2 types, and tumor-associated macrophages (TAMs) in the tumor microenvironment are known to exhibit an M2-like phenotype. These TAMderived exosomes induce immune suppression for tumor progression by mediating cell-tocell communication with other immune cells such as T cells [29].

Tumor-derived exosomes (TEXs) released from malignant cells alter the physiology of macrophages [30], reduce the activity of natural-killer (NK) cells [31], and stimulate tumors by regulating the role of T cells (Figure 2) [32]. TEXs also play an important role in tumor metastasis by regulating the tumor microenvironment (TME) [33,34]. For example, breast cancer cell-derived exosomes deliver certain oncogenic proteins and miRNAs such as miRNA-130a and miRNA-328, which contribute to increase tumor growth and metastasis [35]. Exosomes derived from human pancreatic cells promote metastasis and are critically relevant to the immune-suppressive functions [36]. Similarly, Wang et al. identified that TEXs in gastric tumor cell microenvironment develop primary tumor growth by inducing an immunosuppressive $\mathrm{PD}^{+}$tumor-associated macrophages population that inhibits $\mathrm{CD}^{+} \mathrm{T}$-cell function [37]. The study of TEXs being involved in angiogenesis has also been widely described. Angiogenesis is the key hallmark of tumor progression, which is directly involved in tumor progression by supplying tumor-associated blood vessels and the target of the cancer immunotherapy. TEXs participate in inducing new vessels at the early stage of cancer development in various tumor types including glioblastoma, malignant mesothelioma, and hypoxic lung cancer [38]. Additionally, the amount of these TEXs is 10 times greater than the exosomes released from normal cells due to alterations in the tumor metabolism.

Therefore, the application of TEX as biomarkers of cancer therapy is becoming increasingly developed due to their function in TME. The role of TEXs as a biomarker has been studied in various recent studies. One study demonstrated that TEXs in non-small cell lung cancer (NSCLC) could also be used as therapeutic biomarkers as potential cancer diagnostic indicators [39]. The other study led by Mousavi et al. investigated that TEXs controlling cancer development could be potential biomarkers of colorectal cancer by detecting exosomes containing tumor-related miRNAs [40].

These findings including various effects of TEXs on cancer pathogenesis support that they may become potential therapeutic agents and tools for cancer therapy. 


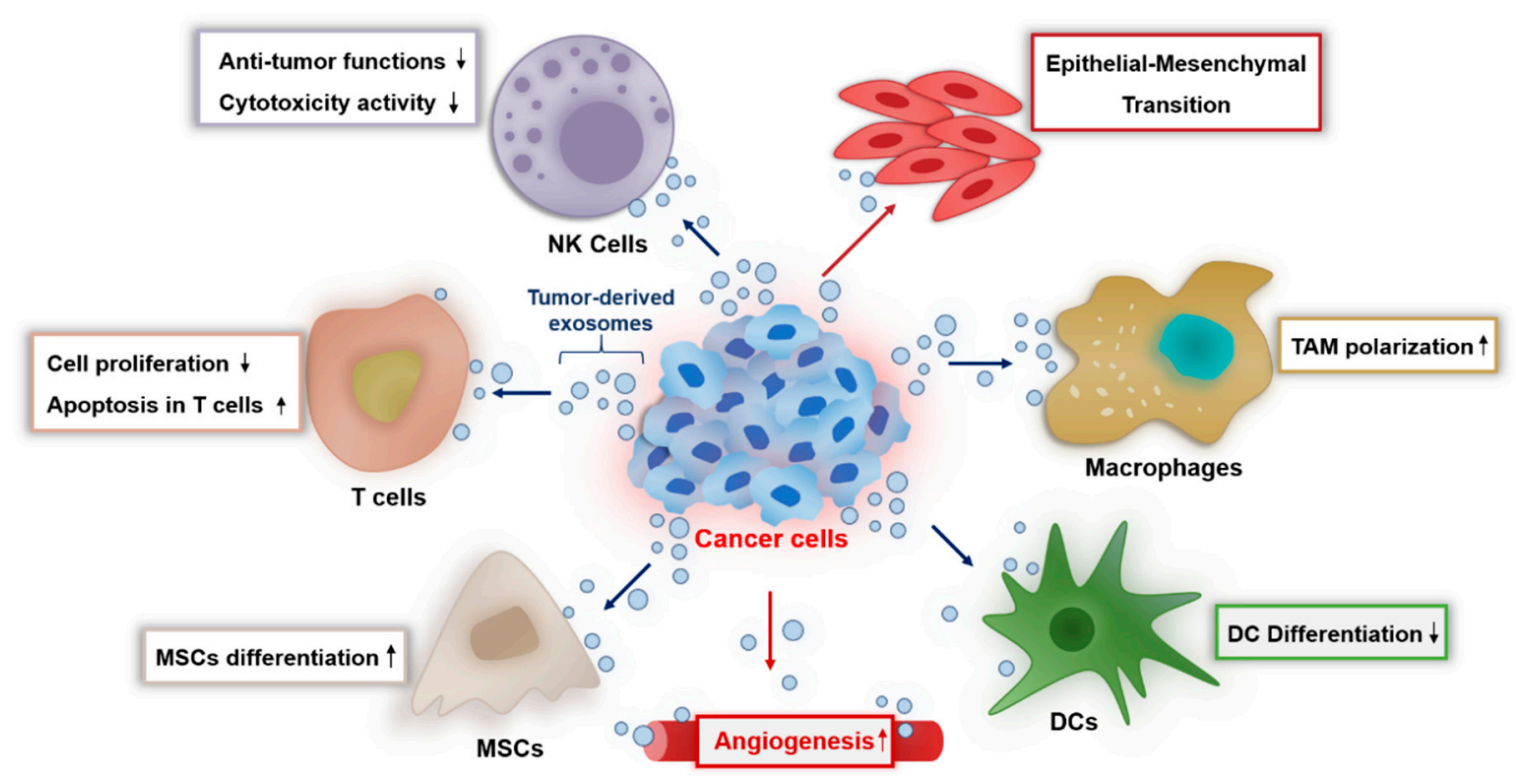

Figure 2. Overview of the role of tumor-derived exosomes in the tumor microenvironment. Exosomes secreted by cancer cells can induce epithelial-mesenchymal transition in other cancer cells and promote the differentiation of mesenchymal stem cells (MSCs). Cancer cells can promote angiogenesis and polarize macrophages to tumor-associated macrophages (TAM), a tumor-supporting phenotype. Tumor-derived exosomes are able to suppress the antitumor response of immune cells such as natural-killer (NK) cells, T cells, and dsendritic cells (DCs).

\section{Exosomes as Drug Delivery Vehicles}

As mentioned previously, cell-derived exosomes have shown potential therapeutic effects through cargo contents and functions received from donor cells. This potential can be maximized by engineering the exosome as a natural nanoplatform for drug delivery. With the advancement of nanotechnology, nanomedicine has made an important contribution to improving the loading capacity, biodistribution, and target accumulation of therapeutic molecules [41]. The advances in the field of nanomedicine have been applied to exosomes through the encapsulation of therapeutic molecules and modification of the exosomal membranes (Figure 3).

\subsection{Encapsulation of Therapeutic Molecules}

Recently, many papers have reported the loading of a variety of therapeutic molecules including chemical drugs, proteins, and nucleic acids into exosomes. As a nanoplatform, the inner space of exosomes can be the room for drug loading. In addition, as previously mentioned, exosomes have internal contents, including proteins and miRNAs, inherited from donor cells. The use of exosomes as a drug delivery vehicle can be mainly discussed in four ways: (1) co-incubation, (2) membrane permeability enhancement, (3) cytoplasmic abundance in donor cells, and (4) selective encapsulation in exosome. 


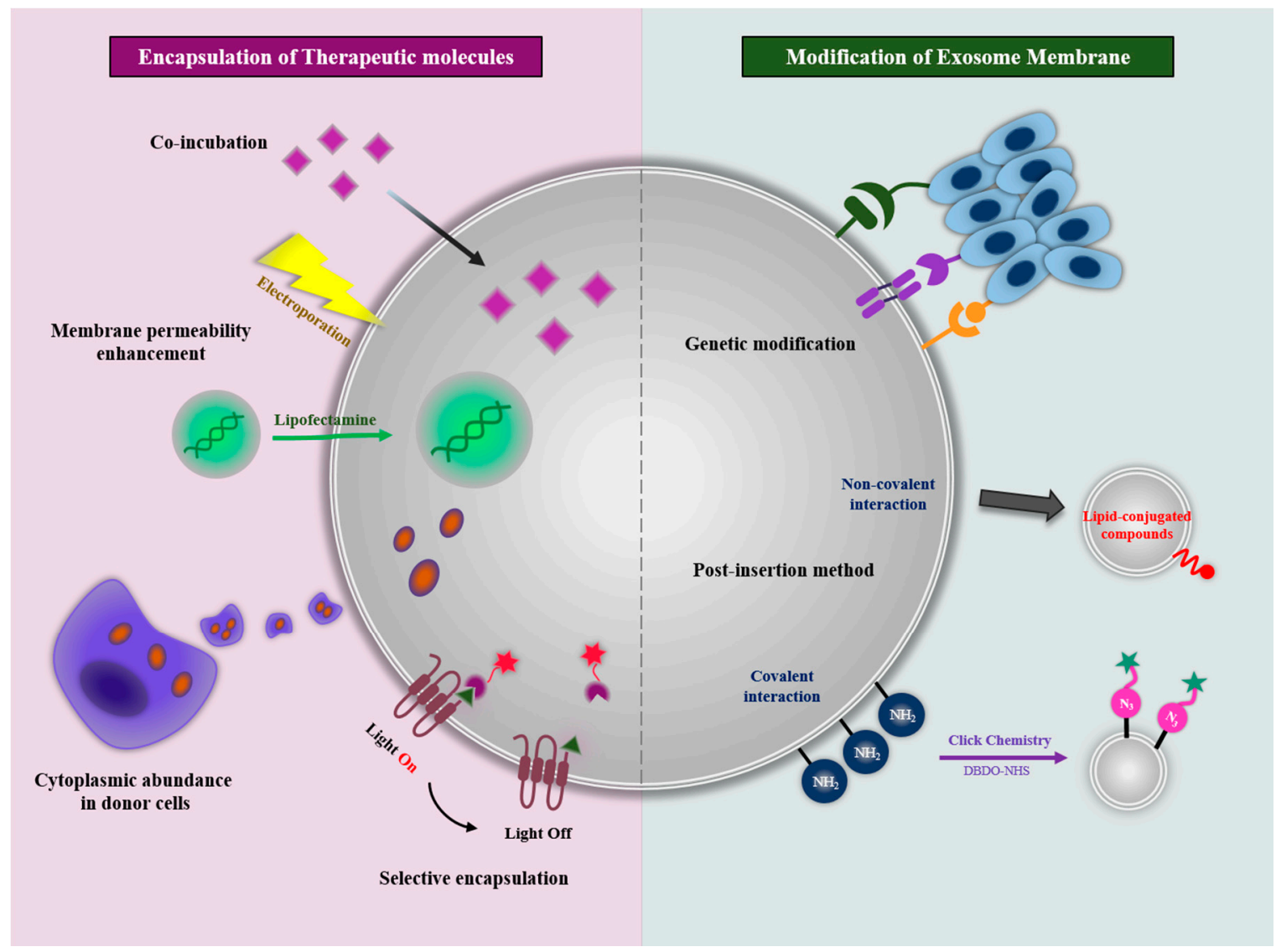

Figure 3. Engineering methods of exosomes as a nanoplatform for improving therapeutic efficacy. Exosomes could be therapeutically engineered with the encapsulation of therapeutic molecules and modification of the exosome membrane. Encapsulation methods involve co-incubation (direct mixing), membrane permeability enhancement (physical/chemical stimuli), cytoplasmic abundance in donor cells, and selective encapsulation via machinery related with exosome biogenesis and release. Membrane modification methods involve genetic modification and the post-insertion method.

\subsubsection{Co-Incubation}

Co-incubation with exosomes and therapeutic molecules is the simplest encapsulation method using the space of the membrane lipid bilayer. The small hydrophobic molecules such as curcumin [42] and doxorubicin [43] were able to be loaded by incubation with exosomes for $5 \mathrm{~min}$ and $1 \mathrm{~h}$ in RT and $37^{\circ} \mathrm{C}$, respectively. The incorporation of hydrophobic drugs into exosomes increased the solubility and stability of the hydrophobic drugs in blood circulation. In addition, the accumulation of drug-loaded exosomes at brain tumors was observed across the blood-brain barrier through the biodistribution change of hydrophobic drugs. However, the molecules that can be loaded into exosomes by coincubation are limited to hydrophobic small molecules that interact with the exosomal membranes. Molecules with high molecular weight, such as proteins and nucleic acids, are difficult to be loaded into exosomes by this way. In addition, even small hydrophobic molecules cannot fully utilize the internal capacity of exosomes with co-incubation methods. Therefore, various drug encapsulation methods have been developed to increase the loading capacity regardless of the chemical properties and molecular weight of the therapeutic molecule.

\subsubsection{Membrane Permeability Enhancement}

To overcome the limitations of the co-incubation method, new approaches have been proposed to improve exosomal membrane permeability through physical or chemical stimulation. These stimulations are commonly used methods to improve intracellular uptake or 
induce the membrane deformation of cells, and they can also be applied to exosomes with the same membrane structure. Membrane permeability can be improved by the generation of pores on the exosomal membranes, disruption of membrane integrity, or transfection with positively charged agents. While these approaches ideally increase drug loading efficiency, the aggregation of exosomal membranes can be induced by these stimulations.

As pore generating stimuli, electroporation and saponin permeabilizer have been studied for membrane permeability enhancement. Electroporation is a method of incubating exosomes with the desired therapeutic agents and exposing them to a repetitive electric field of a certain voltage to make a pore in the exosomal membranes to encapsulate therapeutic agents [44]. This method has been applied preferentially when incorporating nucleic acids such as siRNA, mRNA, and miRNA into exosomes, and it showed efficient encapsulation, but a size-dependent limitation was still observed in the electroporation of large linear DNAs [45]. As another method, a saponin permeabilizer is a surfactant that can make pores via cholesterol removing without ruining the cellular membranes [46]. Fuhrmann et al. reported the encapsulation of porphyrins, a cytotoxic drug for photodynamic therapy, into exosomes using saponin permeabilizer [47]. Saponin-mediated encapsulation increased the drug-loading efficiency compared to the methods for the co-incubation, electroporation, and extrusion. However, since saponin has hemolytic activity [48] and is difficult to remove from exosomes, the amount of saponin used for drug loading should be controlled for in vivo applications.

To disrupt exosomal membrane integrity, sonication has been explored for drug encapsulation into exosomes. The membrane deformation through the ultrasonic homogenizer probe causes the drugs to diffuse into exosomes. Kim et al. demonstrated that exosomal membrane microviscosity was decreased by sonication [49]. As the size of exosomes increased, sonication loaded a higher concentration of paclitaxel within exosomes compared with other methods, including co-incubation and electroporation. These paclitaxel-loaded exosomes showed effective antitumor activity in a metastatic lung cancer mouse model. Another exosomal membrane disruption method for drug loading is the extrusion. During extrusion, the exosomes undergo mechanical stress while passing through the narrow pores, and their membranes are disrupted and vigorously mixed with the drugs. In addition, Haney et al. reported the catalase encapsulation in exosomes using extrusion [50]. The catalases and exosomes were extruded 10 times with $200 \mathrm{~nm}$ pores. With this extrusion condition, catalase-loaded exosomes exhibited higher drug-loading efficiency compared with the co-incubation method. Similar to sonication, exosome size was increased after extrusion. However, accurate understanding about how to change the membrane structure and property is still insufficient.

Lastly, therapeutic nucleic acids can be loaded into the exosomes with transfection agents. Shyam et al. showed siRNA encapsulation in exosomes using a commercial transfection agent, lipofectamine [51]. The RAD51 siRNAs were mixed with lipofectamine at RT for $10 \mathrm{~min}$; then, the exosomes were added into the mixture and incubated at RT for $30 \mathrm{~min}$. After purification, the siRNA-loaded exosomes showed siRNA transfer to recipient cells and induced therapeutic effects. However, the method using the lipofectamine exhibited low drug loading efficiency compared with the electroporation method.

\subsubsection{Cytoplasmic Abundance in Donor Cells}

One of the main approaches for drug encapsulation into exosomes is the overexpression of the drug in donor cells. Therapeutic molecules including chemicals, nucleic acids, proteins, and nanoparticles in the cytoplasm can be loaded in the exosomes due to their abundance. Pascucci et al. treated a low dose of paclitaxel to mesenchymal stroma cells for $24 \mathrm{~h} \mathrm{[52].} \mathrm{After} \mathrm{subculture,} \mathrm{the} \mathrm{paclitaxel-loaded} \mathrm{exosomes} \mathrm{were} \mathrm{obtained} \mathrm{from} \mathrm{the}$ mesenchymal stroma cells. These exosomes inhibited proliferation of CFPAC-1 human pancreatic cells in vitro. Zhang et al. transfected siRNA for hepatocyte growth factor (HGF) to human embryonic kidney 293T (HEK293T) cells [53]. The HGF siRNA were contained in isolated exosomes and transferred to the SGC-7901 cancer cells. Furthermore, 
exosomes loaded with HGF siRNA showed antitumor effects via HGF silencing in vivo by intravenous tail injections. Therapeutic nanoparticles also can be loaded into exosomes. Silva et al. investigated combining magnetic nanoparticles with therapeutic drugs [54]. The iron oxide nanoparticles and drugs ingested by THP-1 macrophage cells were successfully loaded into the exosomes. The loaded exosomes were magnetically responsive and manipulated by magnetic forces.

Collectively, the method inducing the cytoplasmic abundance in donor cells showed a facile encapsulation of various therapeutic molecules with a simple mechanism. However, note that the toxicity of donor cells and inefficient drug loading limit its broad applications.

\subsubsection{Selective Encapsulation in Exosome}

To overcome the limitations of the method for cytoplasmic abundance in donor cells, a method of selective drug encapsulation into donor cells was explored. Particularly, unlike chemical drugs, large molecules including proteins and nucleic acids are hardly passively encapsulated into the exosome lumen. However, therapeutic molecules can be selectively loaded into exosomes by targeting the constituent proteins of exosomes involved in exosome biogenesis and packaging (e.g., ESCRT machinery). The interaction between the constituent protein of the exosome and the therapeutic molecule leads to a specific encapsulation of the molecule into the exosome.

Di Bonito reported a fusion protein which is the Nef exosome-anchoring protein fused with human papillomavirus E7 (Nef/E7) for exosome-based immunization. [55]. The Nef/E7 fusion protein was successfully loaded into exosomes with Nef specific manner. The Nef/E7-loaded exosomes induced an E7-specific immune response in vivo. Another target for selective encapsulation is ESCRT machinery. In a similar approach, targeting chicken egg ovalbumin (OVA) to exosomes was achieved by fusing it to the $\mathrm{C} 1 \mathrm{C} 2$ domain of lactadherin that has an intrinsic property to bind to lipid membranes [56]. De Gassart et al. made a chimeric protein containing the cytosolic domain of the viral Env protein and the ectodomain of CD8 (CDTM-BLVeCD8) [57]. The CDTM-BLVeCD8 was found to be very efficient in exosomes via peptide motifs potentially recognized by components of the ESCRT machinery in K562 cells. In addition, as a light triggering an active encapsulation method, Yim et al. reported the exosomes for protein loading via optically reversible protein-protein interactions (EXPLORs) [58]. The reversible interaction was conducted between a photoreceptor cryptochrome 2 (CRY2) and CRY-interacting basic-helix-loophelix (CIBN) by blue-light illumination. Interaction between a CRY2-cargo protein and a CIBN-CD9 protein induced the cargo loading into exosomes with light. The encapsulation method using the constitutive proteins of exosomes showed an efficient selective loading of the therapeutic molecules into exosomes.

For the selective encapsulation of nucleic acids into exosomes, exosome-enriched RNAs (eRNAs) have been studied with the distinguishing of enriched sequences in the exosomes [59]. The eRNAs share three specific sequence motifs including ACCAGCCU, CAGUGAGC, and UAAUCCCA that may function as cis-acting elements targeting to exosomes. These results aid in our understanding of the selective targeting of candidate RNAs for therapeutic purposes. In addition, tumor-suppressor miRNAs present in tumorderived exosomes were investigated. For example, Teng et al. reported the major vault protein (MVP)-mediated selective sorting of tumor suppressor miRNA, miR-193a [60]. The knockout of MVP failed to sort miR-193a into exosome and caused miRNA accumulation in the donor cancer cells. The key elements of the RNA-induced silencing complex (RISC), GW182 and AGO2, are known to be related to the MVBs and may be involved in the distribution of miRNAs to exosomes [3,61]. In addition, the depletion of Myoferlin in cancer-derived exosomes was shown to have functionally reduced capacity to transfer nucleic acids to human endothelial cells [62].

These proteins such as MVP, GW182, AGO2, and Myoferlin may be be a tool for loading specific nucleic acids into exosomes. More detailed and accurate bioinformatics analysis will be needed to discover new targets for encapsulation into exosomes. 
Although exosomes have promising therapeutic potential, there are several challenges that must be overcome before transitioning from the laboratory stage to clinical use. Some of these challenges include the low yield of exosomes and non-standardized isolation and purification methods. In order to overcome these hurdles, biomimetic exosomes that can be generated in all cell types with characteristics similar to exosomes for an alternative therapeutic drug modality have been developed and studied (Table 1).

Table 1. Studies for the loading of therapeutic molecules into exosome.

\begin{tabular}{|c|c|c|c|c|}
\hline Method & Drug Loaded & Advantages & Disadvantages & References \\
\hline \multicolumn{5}{|l|}{$\begin{array}{l}\text { Passive Loading } \\
\text { Methods }\end{array}$} \\
\hline Incubation with Drugs & $\begin{array}{l}\text { Small hydrophobic } \\
\text { molecules } \\
\text { (curcumin and } \\
\text { doxorubicin) }\end{array}$ & $\begin{array}{l}\text { Simplest method } \\
\text { Increasing solubility and } \\
\text { stability of the hydrophobic } \\
\text { drugs in blood circulation }\end{array}$ & $\begin{array}{c}\text { Low drug-loading efficiency } \\
\text { Not efficient for large } \\
\text { molecules }\end{array}$ & {$[42,43]$} \\
\hline \multicolumn{5}{|l|}{$\begin{array}{l}\text { Active Loading } \\
\text { Methods }\end{array}$} \\
\hline Electroporation & $\begin{array}{c}\text { Chemotherapeutic } \\
\text { drug (doxorubicin and } \\
\text { paclitaxel) }\end{array}$ & $\begin{array}{c}\text { Loading with large } \\
\text { molecules possible } \\
\text { Applicable for nucleic acids }\end{array}$ & $\begin{array}{c}\text { Low drug-loading efficiency } \\
\text { (hydrophobic drugs) } \\
\text { Cargo aggregation }\end{array}$ & {$[45,63,64]$} \\
\hline Sonication & $\begin{array}{l}\text { Chemotherapeutic } \\
\text { drug (doxorubicin and } \\
\text { paclitaxel), } \\
\text { small RNAs }\end{array}$ & $\begin{array}{l}\text { High drug-loading efficiency } \\
\text { Applicable for nucleic acids }\end{array}$ & $\begin{array}{l}\text { Deformation of membrane } \\
\text { Low drug-loading efficiency } \\
\text { (hydrophobic drugs) }\end{array}$ & {$[49,65]$} \\
\hline Extrusion & Catalase & High drug-loading efficiency & $\begin{array}{l}\text { Deformation of membrane } \\
\text { Limitation of membrane }\end{array}$ & [50] \\
\hline $\begin{array}{l}\text { Freeze and Thaw } \\
\text { Cycles }\end{array}$ & Proteins and peptides & $\begin{array}{l}\text { Fusion of membranes } \\
\text { possible }\end{array}$ & $\begin{array}{l}\text { Low drug-loading efficiency } \\
\text { Exosome aggregation }\end{array}$ & {$[50,66]$} \\
\hline Click Chemistry & Drugs and nucleic acids & $\begin{array}{c}\text { Quick and efficient reactions } \\
\text { High specificity }\end{array}$ & $\begin{array}{l}\text { Impairing the functionality } \\
\text { of surface proteins }\end{array}$ & [67] \\
\hline \multicolumn{5}{|l|}{ Exosome-mimic } \\
\hline Mimetic Nanovesicles & $\begin{array}{c}\text { Chemotherapeutic } \\
\text { drug (doxorubicin and } \\
\text { paclitaxel) }\end{array}$ & $\begin{array}{l}\text { Easier to manufacture } \\
\text { High the therapeutic } \\
\text { delivery efficiency } \\
\text { High yield production }\end{array}$ & $\begin{array}{l}\text { Require to understand cargo } \\
\text { loading } \\
\text { (cellular uptake, cargo } \\
\text { release, and fate of vesicles) }\end{array}$ & {$[68-71]$} \\
\hline
\end{tabular}

\subsection{Modification of Exosomal Membranes}

The exosomal membranes, the surface of the nanoplatform, is exposed to the external environment. In the field of nanomedicine, surfaces play an important role in therapeutic applications including extended circulation and specific activity targeting. Exosomes have the same composition and formation as the donor cell membrane. Thus, they express an intrinsic membrane pattern that includes lipid composition, adhesion molecules, specific ligands, and membrane-associated enzymes. The exosome engineering with modification of their membrane mainly focused on adjusting this pattern to increase the therapeutic effect.

Exosomal membranes can be modified with membrane proteins expressed by transfection with plasmid DNAs or mRNAs in donor cells. Since membrane proteins on the cellular membranes are inherited to exosomes with the native forms associated with lipid bilayers, the exosome is a unique platform for maximizing the membrane protein activity [72]. With membrane modification through the expression of functional membrane proteins, engineered exosomes could have a new targeting ability and exhibit the extension of circulation time. For example, it has been reported the HEK293T cells-derived exosomes 
expressing the exosomal protein Lamp2b fused with interleukin 3 (IL3). The exosomes were able to selectively target Chronic Myeloid Leukemia cells that overexpress IL3 receptors [73]. Lamp2b was also used to specific delivery therapeutic exosomes to the mouse brain. Targeting was achieved by engineering the dendritic cell-derived exosomes to express Lamp2b fused to the neuron-specific RVG peptide [74]. Another study showed that the signal-regulatory protein alpha (SIRP $\alpha$ ) modified exosomes for blocking the "don't eat me" signal via targeting CD47 on tumor cells [75]. For the effective expression of SIRP $\alpha$ proteins on exosomal membranes, the SIRP $\alpha$ ectodomain was inserted in pDisplay vector. The engineered exosomes expressing SIRP $\alpha$ was able to antagonize CD47 on tumor cells in vitro, and they successively accumulated at tumor sites, inhibiting tumor growth in vivo. Since the transmembrane domain of platelet-derived growth factor receptor-beta (PDGFR- $\beta$ ) of the pDisplay vector has a property to dimerize by itself at lipid raft domains, $\operatorname{SIRP} \alpha$ proteins could induce efficient CD47 blockade with higher affinity compared with monomeric SIRP $\alpha$ when expressed on the exosomal surface. The SIRP $\alpha-C D 47$ interaction also was used for the extension of blood circulation time of exosomes. Kamerkar et al. suggested that CD47-modified exosomes were protected from phagocytosis by monocytes and macrophage [76]. The exosomes with high levels of CD47 expression showed higher retention in the circulation, resulting in enhanced RNAi delivery to specifically target oncogenic KRAS in pancreatic tumors.

Alternatively, rather than using molecular cell biology approaches to enable downstream modifications of exosome surface macromolecules, exosomal membranes can be modified by post-insertion methods. The post-isolation modification techniques enable the functionalization of exosome surfaces with specific moieties to improve targeting ability and biodistribution and allow tracking in vivo and in vitro. The exosome surface can be essentially modified by (i) covalent interaction between functionalizing molecules or the chemical linker and the amine groups, which are reactive functional units widely expressed on exosomes' surfaces, and (ii) non-covalent interaction based on lipid-conjugated compounds post-insertion into exosomal membranes. Recent study has reported that polyethylene glycol (PEG)-modified exosomes were able to avoid opsonization and extend the circulation half-life of exosomes. These exosomes were modified through the incorporation of 1,2-distearoyl-sn-glycero-3-phosphoethanolamine into the lipid layer of the exosome. Furthermore, for targeting lymph nodes, the PEG's distal end was functionalized with amine groups followed by conjugating with mannose-isothiocyanate [77]. Kim et al. also reported the PEGylated exosomes having a targeting moiety [78]. They developed the aminoethyl anisamide-polyethylene glycol (AA-PEG) vector to target the sigma receptor overexpressed by lung cancer cells. The AA-PEG vector had the 1,2-distearoyl-sn-glycero3-phosphoethanolamine for the interaction with the exosomal membranes. The exosomes derived from bone marrow-derived macrophages mixed with AA-PEG vector and showed accumulation at cancers with systemic administration. Other post-isolation functionalization techniques can utilize specific receptors or antigens. For example, as the A33 antigen has been proven to be overexpressed in colorectal cancer cells, exosomes isolated from these cells present the A33 antigen on their surface. These exosomes are loaded with doxorubicin and functionalized with superparamagnetic iron oxide nanoparticles coated with high-density A33 antibodies, showing antitumor activity toward colorectal cancer with reduced systemic toxicity [79].

In this way, the development of exosomal membrane engineering technology can maximize the efficacy of exosomes through an improved circulation time and targeting ability of exosomes.

\section{Therapeutic Applications of Exosomes for Cancer Therapy}

With advantages such as high biocompatibility, increased circulating stability, low immunogenicity, and toxicity, exosomes can be used as attractive therapeutic delivery vehicles for delivering functional genetic material to the targeted cells. A number of studies 
have been conducted to show that a variety of cell-derived exosomes can be used as therapeutic agents for cancer therapy (Table 2).

\subsection{Tumor-Derived Exosomes}

TEXs are commonly used with chemotherapeutics to enhance the efficacy of cancer treatment because it is easy to deliver to tumor cells through the surface proteins of TEX. TEXs loaded with doxorubicin through electroporation showed a considerable inhibition of tumor growth than the free doxorubicin group and also showed the cardioprotective effect by restricting the uptake to myocardial endothelial cells [63].

Tumor cells express antigens that can be recognized by cytotoxic $\mathrm{T}$ lymphocytes (CTLs). TEXs are also able to present tumor antigens, indicating that TEXs can be modified for cancer immunotherapy. Previous studies have shown that dendritic cells (DCs) can take up TEXs containing donor antigens and induce antigen-specific CTL responses in vitro or in vivo. As a result of the stronger CTL activation and faster DC uptake rate, the tumorsuppression effect of TEX-loaded DCs was significantly higher than that of tumor lysateloaded DCs in a myeloid leukemia WEHI-3B-bearing mouse model [80]. Meanwhile, TEXs are also used in immune suppressors that efficiently regulate tumor-related immune response through modulating the signaling pathway, maintaining the effects of regulatory $T$ cells and processing enzymatic activity [81]. Rong et al. found that TEXs in breast cancer act as critical immune suppressors by carrying transforming growth factor- $\beta$, which is a potent immunosuppressive factor on $\mathrm{T}$ cell expression [82].

Recent research has confirmed that the M2 isoform of pyruvate kinase plays a key role in catalyzing glycolysis. Circular RNA identified as a sponge of miR-122 targeting PKM2 was loaded onto TEXs and delivered to drug-resistant colorectal cancer. TEXs inhibited glycolysis by reprogramming tumor metabolism, weakened drug resistance, and showed excellent anticancer effects in in vitro and in vitro experiments [83]. TEX, which is also involved in the progression and metastasis of cancer, has been extensively studied as a biomarker for the diagnosis of cancer and for monitoring the formation of atherosclerosis, but targeting a specific function of TEX could also be a promising therapeutic approach for preventing or delaying cancer recurrence.

Table 2. Summary of studies using exosomes for cancer therapy.

\begin{tabular}{|c|c|c|c|c|}
\hline Source of Exosome & Strategy & Outcome & Target Cancer Type & References \\
\hline \multicolumn{5}{|l|}{$\begin{array}{l}\text { Tumor cell-derived } \\
\text { exosome }\end{array}$} \\
\hline $\begin{array}{l}\text { Human breast cancer } \\
\text { (MDA-MB-231) }\end{array}$ & $\begin{array}{l}\text { Loading with doxorubicin through } \\
\text { electroporation }\end{array}$ & $\begin{array}{l}\text { Inhibition of tumor } \\
\text { progression and } \\
\text { enhancing the } \\
\text { cytotoxicity of } \\
\text { doxorubicin }\end{array}$ & Breast & [63] \\
\hline $\begin{array}{l}\text { Human breast cancer } \\
\text { (MDA-MB-231 and } \\
\text { BT-474) }\end{array}$ & $\begin{array}{l}\text { Carrying transforming growth } \\
\text { factor- } \beta \text { (TGF- } \beta \text { ) and interleukin-10 } \\
\text { (IL-10) which exhibit the } \\
\text { immune-regulatory functions, a } \\
\text { potent immunosuppressive factor on } \\
\text { T cell expression }\end{array}$ & $\begin{array}{l}\text { Providing biomarkers } \\
\text { for cancer diagnosis }\end{array}$ & Breast & [82] \\
\hline $\begin{array}{l}\text { Human glioblastoma } \\
\text { (A172) }\end{array}$ & $\begin{array}{l}\text { Carrying angiogenic proteins and } \\
\text { RNA that induce new vessels at the } \\
\text { early stage of cancer development }\end{array}$ & $\begin{array}{l}\text { Providing biomarkers } \\
\text { for cancer diagnosis }\end{array}$ & Glioblastoma & [38] \\
\hline $\begin{array}{l}\text { Non-small cell lung } \\
\text { cancer (from NSCLC } \\
\text { patients) }\end{array}$ & $\begin{array}{l}\text { Carrying exosomal proteins such as } \\
\text { alpha-2-HS-glycoprotein (AHSG) and } \\
\text { extracellular matrix protein } 1 \text { (ECM1) }\end{array}$ & $\begin{array}{l}\text { Providing biomarkers } \\
\text { for cancer diagnosis }\end{array}$ & $\begin{array}{l}\text { Non-small cell lung } \\
\text { cancer (NSCLC) }\end{array}$ & [39] \\
\hline
\end{tabular}


Table 2. Cont.

\begin{tabular}{ccccc}
\hline Source of Exosome & Strategy & Outcome & Target Cancer Type & References \\
\hline $\begin{array}{c}\text { Colorectal cancer } \\
\text { Stem cell-derived } \\
\text { exosome }\end{array}$ & $\begin{array}{c}\text { Increasing the transfer of small } \\
\text { molecules including growth factors, } \\
\text { chemokines, and RNAs }\end{array}$ & $\begin{array}{c}\text { Providing biomarkers } \\
\text { for cancer diagnosis }\end{array}$ & Colorectal cancer \\
\hline $\begin{array}{c}\text { Mouse bone marrow } \\
\text { MSCs (BM-MSCs) }\end{array}$ & $\begin{array}{c}\text { Carrying MiR-16, which } \\
\text { downregulates the expression of } \\
\text { VEGF in the TME }\end{array}$ & $\begin{array}{c}\text { Inhibition of } \\
\text { angiogenesis }\end{array}$ & Breast cancer (4T1) \\
\hline Human MSCs & $\begin{array}{c}\text { Carrying MiR-100, which } \\
\text { downregulates the expression of } \\
\text { VEGF by modulating mTOR/HIF-1 } \alpha \\
\text { signaling }\end{array}$ & $\begin{array}{c}\text { Inhibition of } \\
\text { angiogenesis }\end{array}$ & $\begin{array}{c}\text { Breast cancer (MCF-7 } \\
\text { and MDA-MB-231) }\end{array}$ \\
\hline [85]
\end{tabular}

Immune cell-derived

exosome

\begin{tabular}{|c|c|c|c|c|}
\hline \multirow{5}{*}{ Dendritic cell (DC) } & $\begin{array}{l}\text { Activating NK cells and T cells and } \\
\text { inducing the secretion of interferon- } \gamma \\
(\text { IFN- } \gamma)\end{array}$ & $\begin{array}{l}\text { Inhibition of tumor } \\
\text { progression }\end{array}$ & $\begin{array}{l}\text { Melanoma (B16), } \\
\text { Colon } \\
\text { adenocarcinoma } \\
\text { (MC38), Squamous } \\
\text { cell carcinoma } \\
\text { (KLN205) }\end{array}$ & [87-89] \\
\hline & & & $\begin{array}{l}\text { Non-small cell lung } \\
\text { cancer (NSCLC) }\end{array}$ & [90] \\
\hline & $\begin{array}{l}\text { Loading factors that stimulate a wide } \\
\text { range of immune cells to enhance } \\
\text { antigen-specific T cell responses }\end{array}$ & $\begin{array}{l}\text { Inhibition of tumor } \\
\text { progression }\end{array}$ & $\begin{array}{l}\text { Melanoma } \\
\text { (B16/OVA) }\end{array}$ & [91] \\
\hline & $\begin{array}{c}\text { Enhancing antitumor immunity } \\
\text { through TRL3 stimulation during the } \\
\text { maturation of bone marrow derived } \\
\text { DCs }\end{array}$ & $\begin{array}{l}\text { Improve antitumor } \\
\text { immunity and } \\
\text { application in } \\
\text { therapeutic cancer } \\
\text { vaccines }\end{array}$ & Melanoma (B16F10) & [92] \\
\hline & $\begin{array}{l}\text { Expressing hepatocellular carcinoma } \\
\text { antigen } \alpha \text {-fetoprotein through } \\
\text { lentivirus transfection }\end{array}$ & $\begin{array}{l}\text { Inhibition of tumor } \\
\text { progression }\end{array}$ & $\begin{array}{l}\text { Hepatocellular } \\
\text { carcinoma }\end{array}$ & [93] \\
\hline \multirow{3}{*}{ Natural-killer cell (NK) } & $\begin{array}{l}\text { Increasing the proliferation rate of NK } \\
\text { cells involving FasL and perforin }\end{array}$ & $\begin{array}{l}\text { Improve antitumor } \\
\text { immunity }\end{array}$ & Melanoma & [94] \\
\hline & $\begin{array}{c}\text { Treatment with dextran sulfate which } \\
\text { block scavenger receptor A and } \\
\text { preventing the ingestion of exosomes } \\
\text { in the liver }\end{array}$ & $\begin{array}{l}\text { Inhibition of tumor } \\
\text { progression and } \\
\text { improve antitumor } \\
\text { immunity }\end{array}$ & Glioblastoma & [95] \\
\hline & $\begin{array}{l}\text { Activation of human NK cells with } \\
\text { artificial antigen-presenting cells }\end{array}$ & $\begin{array}{l}\text { Inhibition of } \\
\text { proliferation }\end{array}$ & $\begin{array}{c}\text { Acute lymphoblastic } \\
\text { leukemia (SupB15, } \\
\text { NALM-6), } \\
\text { neuroblastoma } \\
\text { (CHLA-136, } \\
\text { CHLA-255), and } \\
\text { breast cancer (MCF7) }\end{array}$ & [96] \\
\hline CD8 + T cells & $\begin{array}{l}\text { Inducing the apoptosis of } \\
\text { mesenchymal stem cells }\end{array}$ & $\begin{array}{l}\text { Inhibition of tumor } \\
\text { progression }\end{array}$ & $\begin{array}{l}\text { CMS5a, CMS5m, } \\
\text { CMS7, CT26, 4T1, B16 } \\
\text { and B16F10 }\end{array}$ & [97] \\
\hline
\end{tabular}


Table 2. Cont.

\begin{tabular}{|c|c|c|c|c|}
\hline Source of Exosome & Strategy & Outcome & Target Cancer Type & References \\
\hline \multirow[t]{2}{*}{ Macrophages } & $\begin{array}{c}\text { Enhancing a pro-inflammatory } \\
\text { cytokine, which induces the cytotoxic } \\
\text { T cell immune response }\end{array}$ & $\begin{array}{l}\text { Improve antitumor } \\
\text { immunity and } \\
\text { application in } \\
\text { therapeutic cancer } \\
\text { vaccines }\end{array}$ & Melanoma (B16F10) & [98] \\
\hline & $\begin{array}{l}\text { Loading paclitaxel and doxorubicin } \\
\text { through various methods to overcome } \\
\text { multidrug resistance in MDCKMDR1 } \\
(\mathrm{Pgp}+) \text { cells }\end{array}$ & $\begin{array}{l}\text { Enhancing the } \\
\text { cytotoxicity of } \\
\text { paclitaxel and } \\
\text { doxorubicin }\end{array}$ & $\begin{array}{l}\text { Murine Lewis lung } \\
\text { carcinoma cell } \\
\text { subline (3LL-M27) }\end{array}$ & [49] \\
\hline \multicolumn{5}{|l|}{$\begin{array}{l}\text { Other cells-derived } \\
\text { exosome }\end{array}$} \\
\hline \multirow{5}{*}{$\begin{array}{l}\text { Human embryonic } \\
\text { kidney 293T (HEK293T) }\end{array}$} & $\begin{array}{l}\text { Carrying Imatinib or BCR-ABL siRNA } \\
\text { which express IL-3 }\end{array}$ & $\begin{array}{l}\text { Inhibition of tumor } \\
\text { progression }\end{array}$ & $\begin{array}{l}\text { Chronic myelogenous } \\
\text { leukemia (LAMA84, } \\
\text { K562) }\end{array}$ & [73] \\
\hline & 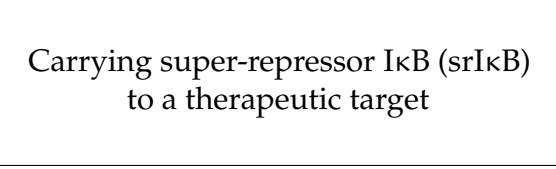 & $\begin{array}{l}\text { Inhibition of } \\
\text { inflammatory } \\
\text { responses }\end{array}$ & $\begin{array}{l}\text { Monocytic THP-1 } \\
\text { cells and human } \\
\text { umbilical vein } \\
\text { endothelial cells }\end{array}$ & [99] \\
\hline & $\begin{array}{c}\text { Carrying therapeutic GPI-anchored } \\
\text { hyaluronidase to the overly } \\
\text { accumulated ECM }\end{array}$ & $\begin{array}{l}\text { Inhibition of tumor } \\
\text { progression and } \\
\text { activation of } \\
\text { infiltration of T cells }\end{array}$ & $\begin{array}{l}\text { Prostate cancer cell } \\
\text { (PC3) }\end{array}$ & [100] \\
\hline & $\begin{array}{l}\text { Loading with doxorubicin through } \\
\text { electroporation }\end{array}$ & $\begin{array}{l}\text { Inhibition of tumor } \\
\text { progression }\end{array}$ & $\begin{array}{l}\text { Primary pulmonary } \\
\text { artery smooth muscle } \\
\text { cells }\end{array}$ & [101] \\
\hline & $\begin{array}{l}\text { Carrying MiR-497 which suppress cell } \\
\text { proliferation, migration and } \\
\text { angiogenesis of tumors }\end{array}$ & $\begin{array}{l}\text { Inhibition of tumor } \\
\text { progression }\end{array}$ & $\begin{array}{l}\text { Non-small cell lung } \\
\text { cancer (NSCLC) }\end{array}$ & [102] \\
\hline \multirow{2}{*}{ Adipocyte } & $\begin{array}{l}\text { Alleviating lung cancer metastasis by } \\
\text { activating MMP9 }\end{array}$ & $\begin{array}{l}\text { Promoting cancer cell } \\
\text { invasion and } \\
\text { metastasis }\end{array}$ & Lung cancer (3LL) & [103] \\
\hline & $\begin{array}{l}\text { Inducing a metabolic reprogramming } \\
\text { in tumor cell }\end{array}$ & $\begin{array}{l}\text { Promoting cancer cell } \\
\text { invasion and } \\
\text { migration }\end{array}$ & Melanoma & [104] \\
\hline
\end{tabular}

\subsection{Stem Cell-Derived Exosomes}

The current study of stem cell-derived exosomes mostly uses MSCs because of their ex vivo expansion capacity and ethical acceptability [105]. Although MSCs are widely used in regenerative medicine due to their immunosuppressive and anti-inflammatory properties, their dual effects of promoting or inhibiting tumor growth have also been reported depending on the progression of cancer or the type of cancer [106]. It has been suggested that this controversial effect of MSCs in the TME depends on their polarization toward a pro-inflammatory or anti-inflammatory phenotype. In addition, they can polarize the immune system that influence tumor development, and similar to MSCs, MSCs-derived exosomes can also exert both anti- or pro-tumorigenic effects.

For example, exosomes derived from mouse bone marrow MSCs (BM-MSCs) have reported to inhibit angiogenesis in breast cancer (4T1) by downregulating VEGF expression in vivo and in vitro [84]. MiR-16, which is abundant in BM-MSC exosomes, was the source of downregulation of VEGF in the TME of breast cancer. Similarly, a study showed that miR-100-rich human MSCs exosomes reduced the expression of VEGF in breast cancer (MCF-7 and MDA-MB-231) in a dose-dependent manner by modulating mammalian target 
of rapamycin (mTOR)/hypoxia-inducible factor- $1 \alpha$ (HIF- $1 \alpha)$ signaling [85]. In addition, the overexpression of miR-124 in human adipose MSCs exosomes has been reported to inhibit ovarian cancer cell proliferation by inducing S-phase arrest through the downregulation of other cyclin-dependent kinases (CDKs) such as CDK2, CDK4, and CDK6 [86]. Despite these reports, there are many findings that MSCs-derived exosomes have a tumorigenic effect. Therefore, more in-depth studies on the relationship between MSCs and cancer are needed for the future safe clinical application of MSCs-derived exosomes for cancer therapy.

\subsection{Immune Cell-Derived Exosomes}

Recent studies have shown that immune cells such as DCs, NK cells, T cells, and macrophages can secrete exosomes that affect many physiological and pathological processes [107]. Thus, immune cell-derived exosomes involved in both immune activation and inhibition have been actively studied as potential therapeutic tools for cancer as well as immune-related diseases.

DCs-derived exosomes (Dexs), the professional antigen-presenting cells necessary to maintain innate and adaptive immunity, have been extensively studied [108]. DCs are involved in both the activation and inhibition of antigen-specific and nonspecific immune responses through the expression of $\mathrm{MHC}$, co-stimulatory, and co-regulatory molecules. Similarly, Dexs are also being studied as therapeutic agents, both applied to immunological activation and inhibition. Compared to DCs, Dexs possess an NK cell lectin-like subfamily $\mathrm{K}$ that can activate NK cells on its surface [88] and also express BCL2-associated athanogene 6, which is known to enhance cytokine release from NK cells [89]. One study suggested that TNF in Dexs could kill tumor cells by activating NK cells and inducing the secretion of IFN$\gamma$ [87]. Similarly, Basse et al. confirmed that Dexs containing IFN- $\gamma$ had immunotherapy efficacy by boosting NK cells and T cells in patients with advanced NSCLC [90]. Strategies for loading factors that stimulate a wide range of immune cells into Dexs have also been recently studied. Bone marrow-derived DCs were fed with $\alpha$-galactosylceramide, which can stimulate IFN- $\gamma$ producing NK T cells, to enhance antigen-specific T cell responses [91]. Exosomes loaded with OVA and $\alpha \mathrm{GC}$ were found to delay tumor progression in a B16OVA-expressing mouse model. Another group confirmed that OVA or tumor lysate-loaded Dexs enhanced antitumor immunity through TRL3 stimulation during the maturation of bone marrow-derived DCs [92]. Moreover, it has been reported that exosomes derived from DCs expressing hepatocellular carcinoma antigen $\alpha$-fetoprotein through lentivirus transfection upregulated not only MHC molecules but also co-stimulatory molecules. These exosomes inhibited tumor growth by increasing the number of IFN- $\gamma$-producing CD8 ${ }^{+} \mathrm{T}$ cells, increasing IL-2 expression, and decreasing regulatory T cells [93].

Similar to Dexs, NK-derived exosomes are also highly promising antitumor therapeutic candidates. NK-derived exosomes are known to contain a typical NK marker such as CD56 and cytotoxic molecules including granulysin, granzyme, perforin, and Fas ligand [96]. One of the unique features of human NK cells is that they secrete lytic granules upon activation. In particular, these lytic granules essentially use their cytotoxic molecules to activate their cellular cytotoxicity [109-111]. One study suggested that the Fas ligand and perforin of NK-derived exosomes increase the proliferation rate of NK cells in vivo and exert antitumor effects in melanoma mouse xenograft models through NK-mediated cytotoxicity [94]. Interestingly, the glioblastoma mouse model was treated with dextran sulfate to block scavenger receptor A, thereby preventing the ingestion of NK exosomes in the liver, resulting in a significant accumulation of exosomes in the tumors [95]. In addition, a method for the large-scale isolation of exosomes derived from activated NK cells through ex vivo expansion culture has been developed, and it has been confirmed to exhibit toxic activity on several cancer cell lines such as acute lymphoblastic leukemia (SupB15, NALM-6), neuroblastoma (CHLA-136, CHLA-255), and breast cancer (MCF7) [96].

While DC-derived exosomes have been extensively studied, there are few studies on exosomes derived from $\mathrm{T}$ cells. $\mathrm{T}$ cell-derived exosomes, similar to their parental cells, are mainly associated with antiviral and antitumor responses, and they carry the TCR/CD3 
complex from activated T cells [64]. One study reported that exosomes derived from CD8 ${ }^{+}$ $\mathrm{T}$ cells can induce the apoptosis of mesenchymal stem cells in tumor-bearing mice, thereby attenuating tumor growth [97]. Chimeric antigen receptor engineered T (CAR-T) cells provide a new strategic method for cancer immunotherapy. The target specificity of CAR-T cells is determined by an antibody-derived single-chain variable fragment in the CAR structure. CAR-T cells show poor therapeutic effects in solid tumors due to stroma-rich matrixes [112]. Thus, cell-free exosomes, which are small nanometers in size, may be able to penetrate the site of the tumor, targeting specific antigens and attacking tumor cells [113].

Macrophage-derived exosomes can also regulate the immune response and induce macrophage polarization. From the results of analyzing the mRNA content of activated macrophages and exosomes derived from these cells, it can be inferred that the state of macrophages was reflected in the secreted exosomes [114]. One study confirmed that exosomes derived from M1 polarized macrophages could be used as immunopotentiators for cancer vaccines [98]. In addition, Paclitaxel-loaded macrophage-derived exosomes overcame multidrug resistance in MDCKMDR1 (Pgp+) cells, resulting in a 50-fold increase in cytotoxicity [49]. Overall, with a deep understanding of the role of immune cell-derived exosomes in cancer and advances in exosome engineering that can enhance the efficacy and targeting ability of exosomes, the potential of immune cell-derived exosomes in cancer therapy is very promising.

\subsection{Other Cells-Derived Exosomes}

In addition to the above-mentioned cells, therapeutic applications using exosomes derived from various cells have been studied. The HEK 293T cell line is often used to deliver exogenous therapeutic proteins, nucleic acids, and drugs. For example, HEK293T cellsderived exosomes-loaded super-repressor IKB inhibits the inflammatory responses by reducing the secretion of the NF- $\mathrm{kB}$-mediated pro-inflammatory cytokines such as TNF- $\alpha$, IL$1 \beta$, and IL-6 contributing to cancer development [99]. In another study, HEK293T-derived exosomes that harbor native $\mathrm{PH} 20$ hyaluronidase were reported. The engineered exosomes were able to penetrate deeply into the tumor foci via the degradation of hyaluronic acids in the extracellular matrix, resulting in tumor growth inhibition and an increased infiltration of T cells into the tumor [100].

Furthermore, another study identified that the encapsulation of doxorubicin in HEK293T-drived exosomes has potential properties for the effective delivery into target cells. The use of engineering exosomes-loaded doxorubicin via electroporation enhances the cellular uptake efficiency and the therapeutic effect compared to other doxorubicin formulations [101]. In the NSCLC model, exosomes derived from HEK293T cells also mediated the transfer of miRNA-497, which significantly suppressed cell proliferation, migration, and the angiogenesis of tumors. The miRNA loaded in exosomes is more stable than the free miRNA and has a longer cycle time, which is advantageous in controlling cancer development [102].

Recently, adipocyte-derived exosomes that are involved in the response and regulation of metabolic states are emerging as promising therapeutic agents. One study reported that 3T3-L1 adipocyte-derived exosomes could enhance the expression of MMP3 in cancer cells that alleviated lung cancer metastasis by activating MMP9 [103]. On the other hand, Lazar et al. observed the role of adipocyte-derived exosomes that are involved in tumor progression and invasion [104].

\section{Challenges and Perspectives}

The outstanding advantage of exosomes as a drug delivery vehicle lies in their biological origin, which is related to their biocompatibility as a natural nanoplatform. In addition, exosomes have excellent performance in prolonging blood circulation time, increasing tumor targeting, and tumor inhibition. Notably, the use of autologous exosomes has suggested a promising therapy as a personalized nanomedicine [90]. However, therapeutic applications of exosomes have encountered critical challenges for clinical use. 


\subsection{Large-Scale Production for the Therapeutic Use of Exosomes}

One of the major challenges to realizing exosomes-based treatments is the low productivity of exosomes. The methods for exosome isolation from the cultured medium are based on ultracentrifuge or filtration at laboratory scales. The yield of exosomes obtained from these methods may vary slightly depending on the type of donor cells but is generally too low. The yield of exosomes is typically less than $1 \mu \mathrm{g}$ of exosomal protein per $1 \mathrm{~mL}$ of culture medium, while the functional dose of exosomes is approximately 10-100 $\mu \mathrm{g}$ exosomal protein per mouse in most studies [115-117]. The exosome-containing medium is generally prepared by culturing exosome-producing cells over several days and varies greatly depending on the type of producing cells, but the number of exosomes in the culture medium reaches the upper limit after about $14 \mathrm{~h}$ of incubation [118]. Thus, bioreactors can be useful for improving the yield of exosomes. One study found that using a hollow fiber bioreactor can increase the yield of exosomes by 5-10 times [119]. However, since the samples obtained also contain larger vesicles (200-800 $\mathrm{nm}$ in diameter), it is not clear whether the yield of exosomes actually increased using a bioreactor. Some studies showed that exosome production was enhanced by providing exosome producing cells with stressful environments such as hypoxia, low $\mathrm{pH}$, and anti-cancer drugs [120-122]. However, the therapeutic effectiveness and safety of exosomes secreted from stressed cells should be carefully evaluated, as cellular stress can alter the composition of exosome content and adversely affect the recipient cells [120]. Additionally, it is likely to overestimate the amount of exosome due to contaminants derived from dead cells such as apoptosis bodies. Therefore, technologies and strategies must be developed to produce quality-controllable exosomes on a large scale and to rapidly purify exosomes.

\subsection{The Heterogeneity of Exosomes}

Recent reports suggest that exosomes derived from the same parent cell may have different molecular composition $[3,123,124]$. In addition, tumor cell-derived exosomes were able to target the donor tumor but exhibited a potential risk of tumorigenesis or improved tumor growth. The heterogeneity of exosomes can also arise due to the difficulty of distinguishing all extracellular vesicles (exosomes, microvesicles, and apoptotic bodies) that share similar properties such as size and density $[1,125,126]$. Therefore, it may be necessary to discover key components that cause therapeutic or side effects for the therapeutic application of exosomes. There are also unmet needs to establish new standards for reporting research on traits such as exosome diversity, content, and origin. Such standards will be essential for incorporating exosomes into clinical use. Indeed, in recent years, many researchers have been working on the analysis of single vesicles for the clinical application of exosomes [127-129]. Ultimately, a better understanding of the heterogeneity and molecular composition of EVs could allow us to determine which subpopulations are better suited for specific exosome-based therapeutics.

In terms of engineering, therapeutic molecules including chemical drugs, nucleic acids, and proteins have been loaded into exosomes. In the process of the engineering, exosomes and donor cells may be affected on exosome content or protein composition. Especially, engineering using physical or chemical stimulation may induce changes in the size and surface potential of the exosome. This may affect the bioactivity and therapeutic efficacy of the exosome. Therefore, exosome engineering should be developed with little impact on the bioactivity, morphology, and composition of exosomes. In addition, similar with content analysis, the developments need to be linked to standards for the evaluation of encapsulation methods.

Despite the challenges, the exosomes have shown a great potential in clinical trials for cancer therapy (Table 3) and would be the next generation of nanoplatforms for advanced therapeutic applications. 
Table 3. Human clinical trials of exosomes in cancer therapy.

\begin{tabular}{ccccc}
\hline Cancer Type & Phase & Source of Exosomes & Results and Status & References \\
\hline Melanoma & Phase I $(n=15)$ & $\begin{array}{c}\text { Immature dendritic cells pulsed } \\
\text { with MAGE 3 tumor peptides }\end{array}$ & Active, Not recruiting \\
\hline $\begin{array}{c}\text { Non-small cell lung } \\
\text { cancer }\end{array}$ & Phase I $(n=4)$ & $\begin{array}{c}\text { Immature dendritic cells pulsed } \\
\text { with MAGE-A3, -A4, -A10, and } \\
\text { MAGE-3DPO4 tumor peptide }\end{array}$ & Recruiting \\
\hline $\begin{array}{c}\text { Non-small cell lung } \\
\text { cancer }\end{array}$ & Phase II $(n=22)$ & $\begin{array}{c}\text { IFN- } \gamma \text { - matured dendritic cells } \\
\text { pulsed with MAGE-A1, -A3, } \\
\text { NY-ESO-1, Melan-A/MART1, } \\
\text { MAGE-A3-DP04, EBV tumor } \\
\text { peptides }\end{array}$ & Recruiting & [131] \\
\hline $\begin{array}{c}\text { Colon cancer } \\
\text { Colon cancer }\end{array}$ & Phase I $(n=40)$ & $\begin{array}{c}\text { Autologous ascites combined } \\
\text { with GM-CSF }\end{array}$ & Active, Not recruiting \\
\hline Pancreatic cancer & Phase I $(n=28)$ & Mesenchymal stem cells & Not yet recruiting & NCT03608631 \\
\hline
\end{tabular}

Author Contributions: All authors (H.K., E.H.K., G.K., S.-G.C., S.H.K., Y.Y.) contributed to writing, reviewing and editing of this work and consented to the final version. All authors have read and agreed to the published version of the manuscript.

Funding: This work was supported by the Mid-career Researcher Program (NRF-2019R1A2C2010408) and the Intramural Research Program of KIST.

Conflicts of Interest: The authors claim no conflict of interest.

$\begin{array}{ll}\text { Abbreviations } \\ \text { EVs } & \text { Extracellular Vesicles } \\ \text { ILVs } & \text { Intraluminal Vesicles } \\ \text { ESCRT } & \text { Endosomal Sorting Complexes Required for Transport } \\ \text { MVBs } & \text { Multivesicular Bodies } \\ \text { MHC II } & \text { Myosin Heavy Chain Class II Proteins } \\ \text { miRNA } & \text { MicroRNA } \\ \text { mRNA } & \text { Messenger RNA } \\ \text { IFN- } \gamma & \text { Interferon } \gamma \\ \text { TEXs } & \text { Tumor-derived exosomes } \\ \text { NK } & \text { Natural-Killer } \\ \text { TME } & \text { Tumor Microenvironment } \\ \text { NSCLC } & \text { Non-Small Cell Lung Cancer } \\ \text { HGF } & \text { Hepatocyte Growth Factor } \\ \text { HEK293T } & \text { Human Embryonic Kidney 293T } \\ \text { OVA } & \text { Ovalbumin } \\ \text { IL3 } & \text { Interleukin 3 } \\ \text { SIRP } \alpha & \text { Signal-Regulatory Protein Alpha } \\ \text { DCs } & \text { Dendritic Cells } \\ \text { MSCs } & \text { Mesenchymal Stem Cells } \\ \text { Dexs } & \text { Exosomes Derived from DCs }\end{array}$

\section{References}

1. Raposo, G.; Stoorvogel, W. Extracellular vesicles: Exosomes, microvesicles, and friends. J. Cell Biol. 2013, 200, 373-383. [CrossRef]

2. Thery, C.; Ostrowski, M.; Segura, E. Membrane vesicles as conveyors of immune responses. Nat. Rev. Immunol. 2009, 9, 581-593. [CrossRef] [PubMed]

3. Valadi, H.; Ekstrom, K.; Bossios, A.; Sjostrand, M.; Lee, J.J.; Lotvall, J.O. Exosome-mediated transfer of mRNAs and microRNAs is a novel mechanism of genetic exchange between cells. Nat. Cell Biol. 2007, 9, 654-659. [CrossRef] [PubMed] 
4. Cossetti, C.; Iraci, N.; Mercer, T.R.; Leonardi, T.; Alpi, E.; Drago, D.; Alfaro-Cervello, C.; Saini, H.K.; Davis, M.P.; Schaeffer, J.; et al. Extracellular vesicles from neural stem cells transfer IFN-gamma via Ifngr1 to activate Stat1 signaling in target cells. Mol. Cell 2014, 56, 193-204. [CrossRef] [PubMed]

5. Mulcahy, L.A.; Pink, R.C.; Carter, D.R. Routes and mechanisms of extracellular vesicle uptake. J. Extracell. Vesicles 2014, 3. [CrossRef] [PubMed]

6. Pironti, G.; Strachan, R.T.; Abraham, D.; Mon-Wei Yu, S.; Chen, M.; Chen, W.; Hanada, K.; Mao, L.; Watson, L.J.; Rockman, H.A. Circulating Exosomes Induced by Cardiac Pressure Overload Contain Functional Angiotensin II Type 1 Receptors. Circulation 2015, 131, 2120-2130. [CrossRef] [PubMed]

7. Lowenstein, P.R.; Mandel, R.J.; Xiong, W.D.; Kroeger, K.; Castro, M.G. Immune responses to adenovirus and adeno-associated vectors used for gene therapy of brain diseases: The role of immunological synapses in understanding the cell biology of neuroimmune interactions. Curr. Gene Ther. 2007, 7, 347-360. [CrossRef] [PubMed]

8. Zhang, J.S.; Liu, F.; Huang, L. Implications of pharmacokinetic behavior of lipoplex for its inflammatory toxicity. Adv. Drug Deliv. Rev. 2005, 57, 689-698. [CrossRef]

9. Ishida, T.; Ichihara, M.; Wang, X.; Yamamoto, K.; Kimura, J.; Majima, E.; Kiwada, H. Injection of PEGylated liposomes in rats elicits PEG-specific IgM, which is responsible for rapid elimination of a second dose of PEGylated liposomes. J. Control. Release 2006, 112, 15-25. [CrossRef]

10. Sun, W.; Luo, J.D.; Jiang, H.; Duan, D.D. Tumor exosomes: A double-edged sword in cancer therapy. Acta Pharmacol. Sin. 2018, 39, 534-541. [CrossRef]

11. Syn, N.L.; Wang, L.; Chow, E.K.; Lim, C.T.; Goh, B.C. Exosomes in Cancer Nanomedicine and Immunotherapy: Prospects and Challenges. Trends Biotechnol. 2017, 35, 665-676. [CrossRef] [PubMed]

12. Thery, C.; Zitvogel, L.; Amigorena, S. Exosomes: Composition, biogenesis and function. Nat. Rev. Immunol. 2002, 2, 569-579. [CrossRef] [PubMed]

13. Ge, R.; Tan, E.; Sharghi-Namini, S.; Asada, H.H. Exosomes in Cancer Microenvironment and Beyond: Have we Overlooked these Extracellular Messengers? Cancer Microenviron. 2012, 5, 323-332. [CrossRef] [PubMed]

14. Booth, A.M.; Fang, Y.; Fallon, J.K.; Yang, J.M.; Hildreth, J.E.; Gould, S.J. Exosomes and HIV Gag bud from endosome-like domains of the T cell plasma membrane. J. Cell Biol. 2006, 172, 923-935. [CrossRef] [PubMed]

15. Mathivanan, S.; Ji, H.; Simpson, R.J. Exosomes: Extracellular organelles important in intercellular communication. J. Proteomics 2010, 73, 1907-1920. [CrossRef] [PubMed]

16. Colombo, M.; Raposo, G.; Thery, C. Biogenesis, secretion, and intercellular interactions of exosomes and other extracellular vesicles. Annu. Rev. Cell Dev. Biol. 2014, 30, 255-289. [CrossRef] [PubMed]

17. Simons, M.; Raposo, G. Exosomes-Vesicular carriers for intercellular communication. Curr. Opin. Cell Biol. 2009, $21,575-581$. [CrossRef]

18. Kowal, J.; Tkach, M.; Thery, C. Biogenesis and secretion of exosomes. Curr Opin. Cell Biol. 2014, 29, 116-125. [CrossRef]

19. Gusachenko, O.N.; Zenkova, M.A.; Vlassov, V.V. Nucleic acids in exosomes: Disease markers and intercellular communication molecules. Biochemistry 2013, 78, 1-7. [CrossRef]

20. Urbanelli, L.; Magini, A.; Buratta, S.; Brozzi, A.; Sagini, K.; Polchi, A.; Tancini, B.; Emiliani, C. Signaling pathways in exosomes biogenesis, secretion and fate. Genes 2013, 4, 152-170. [CrossRef]

21. Melo, S.A.; Sugimoto, H.; O'Connell, J.T.; Kato, N.; Villanueva, A.; Vidal, A.; Qiu, L.; Vitkin, E.; Perelman, L.T.; Melo, C.A.; et al. Cancer exosomes perform cell-independent microRNA biogenesis and promote tumorigenesis. Cancer Cell 2014, 26, 707-721. [CrossRef] [PubMed]

22. Batagov, A.O.; Kurochkin, I.V. Exosomes secreted by human cells transport largely mRNA fragments that are enriched in the 3'-untranslated regions. Biol. Direct 2013, 8, 12. [CrossRef] [PubMed]

23. Balaj, L.; Lessard, R.; Dai, L.; Cho, Y.J.; Pomeroy, S.L.; Breakefield, X.O.; Skog, J. Tumour microvesicles contain retrotransposon elements and amplified oncogene sequences. Nat. Commun. 2011, 2, 180. [CrossRef] [PubMed]

24. Kahlert, C.; Melo, S.A.; Protopopov, A.; Tang, J.; Seth, S.; Koch, M.; Zhang, J.; Weitz, J.; Chin, L.; Futreal, A.; et al. Identification of double-stranded genomic DNA spanning all chromosomes with mutated KRAS and p53 DNA in the serum exosomes of patients with pancreatic cancer. J. Biol. Chem. 2014, 289, 3869-3875. [CrossRef] [PubMed]

25. Zhang, Y.; Liu, D.; Chen, X.; Li, J.; Li, L.; Bian, Z.; Sun, F.; Lu, J.; Yin, Y.; Cai, X.; et al. Secreted monocytic miR-150 enhances targeted endothelial cell migration. Mol. Cell 2010, 39, 133-144. [CrossRef] [PubMed]

26. Wang, C.; Chen, L.; Huang, Y.; Li, K.; Jinye, A.; Fan, T.; Zhao, R.; Xia, X.; Shen, B.; Du, J.; et al. Exosome-delivered TRPP2 siRNA inhibits the epithelial-mesenchymal transition of FaDu cells. Oncol. Lett. 2019, 17, 1953-1961. [CrossRef] [PubMed]

27. Hannafon, B.N.; Gin, A.L.; Xu, Y.F.; Bruns, M.; Calloway, C.L.; Ding, W.Q. Metastasis-associated protein 1 (MTA1) is transferred by exosomes and contributes to the regulation of hypoxia and estrogen signaling in breast cancer cells. Cell Commun. Signal. 2019, 17, 13. [CrossRef] [PubMed]

28. Lugini, L.; Cecchetti, S.; Huber, V.; Luciani, F.; Macchia, G.; Spadaro, F.; Paris, L.; Abalsamo, L.; Colone, M.; Molinari, A.; et al. Immune surveillance properties of human NK cell-derived exosomes. J. Immunol. 2012, 189, 2833-2842. [CrossRef]

29. Zhou, J.; Li, X.; Wu, X.; Zhang, T.; Zhu, Q.; Wang, X.; Wang, H.; Wang, K.; Lin, Y.; Wang, X. Exosomes Released from Tumor-Associated Macrophages Transfer miRNAs That Induce a Treg/Th17 Cell Imbalance in Epithelial Ovarian Cancer. Cancer Immunol. Res. 2018, 6, 1578-1592. [CrossRef] 
30. Mahaweni, N.M.; Kaijen-Lambers, M.E.; Dekkers, J.; Aerts, J.G.; Hegmans, J.P. Tumour-derived exosomes as antigen delivery carriers in dendritic cell-based immunotherapy for malignant mesothelioma. J. Extracell. Vesicles 2013, 2. [CrossRef]

31. Clayton, A.; Mitchell, J.P.; Court, J.; Linnane, S.; Mason, M.D.; Tabi, Z. Human tumor-derived exosomes down-modulate NKG2D expression. J. Immunol. 2008, 180, 7249-7258. [CrossRef] [PubMed]

32. Wieckowski, E.U.; Visus, C.; Szajnik, M.; Szczepanski, M.J.; Storkus, W.J.; Whiteside, T.L. Tumor-derived microvesicles promote regulatory $\mathrm{T}$ cell expansion and induce apoptosis in tumor-reactive activated CD8+ T lymphocytes. J. Immunol. 2009, 183, 3720-3730. [CrossRef] [PubMed]

33. Wang, J.; De Veirman, K.; Faict, S.; Frassanito, M.A.; Ribatti, D.; Vacca, A.; Menu, E. Multiple myeloma exosomes establish a favourable bone marrow microenvironment with enhanced angiogenesis and immunosuppression. J. Pathol. 2016, 239, 162-173. [CrossRef] [PubMed]

34. Zhang, Z.; Dombroski, J.A.; King, M.R. Engineering of Exosomes to Target Cancer Metastasis. Cell Mol. Bioeng 2020, 13, 1-16. [CrossRef] [PubMed]

35. Green, T.M.; Alpaugh, M.L.; Barsky, S.H.; Rappa, G.; Lorico, A. Breast Cancer-Derived Extracellular Vesicles: Characterization and Contribution to the Metastatic Phenotype. Biomed. Res. Int. 2015, 2015, 634865. [CrossRef] [PubMed]

36. Satake, T.; Suetsugu, A.; Nakamura, M.; Kunisada, T.; Saji, S.; Moriwaki, H.; Shimizu, M.; Hoffman, R.M. Color-coded Imaging of the Fate of Cancer-cell-derived Exosomes During Pancreatic Cancer Metastases in a Nude-mouse Model. Anticancer Res. 2019, 39, 4055-4060. [CrossRef]

37. Wang, F.; Li, B.; Wei, Y.; Zhao, Y.; Wang, L.; Zhang, P.; Yang, J.; He, W.; Chen, H.; Jiao, Z.; et al. Tumor-derived exosomes induce PD1(+) macrophage population in human gastric cancer that promotes disease progression. Oncogenesis 2018, 7, 41. [CrossRef]

38. Ahmadi, M.; Rezaie, J. Tumor cells derived-exosomes as angiogenenic agents: Possible therapeutic implications. J. Transl. Med. 2020, 18, 249. [CrossRef]

39. Niu, L.; Song, X.; Wang, N.; Xue, L.; Song, X.; Xie, L. Tumor-derived exosomal proteins as diagnostic biomarkers in non-small cell lung cancer. Cancer Sci. 2019, 110, 433-442. [CrossRef]

40. Mousavi, S.; Moallem, R.; Hassanian, S.M.; Sadeghzade, M.; Mardani, R.; Ferns, G.A.; Khazaei, M.; Avan, A. Tumor-derived exosomes: Potential biomarkers and therapeutic target in the treatment of colorectal cancer. J. Cell. Physiol. 2019, 234, 12422-12432. [CrossRef]

41. Arranja, A.G.; Pathak, V.; Lammers, T.; Shi, Y. Tumor-targeted nanomedicines for cancer theranostics. Pharmacol. Res. 2017, 115, 87-95. [CrossRef] [PubMed]

42. Zhuang, X.; Xiang, X.; Grizzle, W.; Sun, D.; Zhang, S.; Axtell, R.C.; Ju, S.; Mu, J.; Zhang, L.; Steinman, L.; et al. Treatment of brain inflammatory diseases by delivering exosome encapsulated anti-inflammatory drugs from the nasal region to the brain. Mol. Ther. 2011, 19, 1769-1779. [CrossRef] [PubMed]

43. Yang, T.; Martin, P.; Fogarty, B.; Brown, A.; Schurman, K.; Phipps, R.; Yin, V.P.; Lockman, P.; Bai, S. Exosome delivered anticancer drugs across the blood-brain barrier for brain cancer therapy in Danio rerio. Pharm. Res. 2015, 32, 2003-2014. [CrossRef] [PubMed]

44. Weaver, J.C. Electroporation: A general phenomenon for manipulating cells and tissues. J. Cell. Biochem. 1993, 51, 426-435. [CrossRef] [PubMed]

45. Lamichhane, T.N.; Raiker, R.S.; Jay, S.M. Exogenous DNA Loading into Extracellular Vesicles via Electroporation is Size-Dependent and Enables Limited Gene Delivery. Mol. Pharm. 2015, 12, 3650-3657. [CrossRef]

46. Jamur, M.C.; Oliver, C. Permeabilization of cell membranes. Methods Mol. Biol. 2010, 588, 63-66. [PubMed]

47. Fuhrmann, G.; Serio, A.; Mazo, M.; Nair, R.; Stevens, M.M. Active loading into extracellular vesicles significantly improves the cellular uptake and photodynamic effect of porphyrins. J. Control. Release 2015, 205, 35-44. [CrossRef]

48. Podolak, I.; Galanty, A.; Sobolewska, D. Saponins as cytotoxic agents: A review. Phytochem. Rev. 2010, 9, 425-474. [CrossRef]

49. Kim, M.S.; Haney, M.J.; Zhao, Y.; Mahajan, V.; Deygen, I.; Klyachko, N.L.; Inskoe, E.; Piroyan, A.; Sokolsky, M.; Okolie, O.; et al. Development of exosome-encapsulated paclitaxel to overcome MDR in cancer cells. Nanomedicine 2016, 12, 655-664. [CrossRef]

50. Haney, M.J.; Klyachko, N.L.; Zhao, Y.; Gupta, R.; Plotnikova, E.G.; He, Z.; Patel, T.; Piroyan, A.; Sokolsky, M.; Kabanov, A.V.; et al. Exosomes as drug delivery vehicles for Parkinson's disease therapy. J. Control. Release 2015, 207, 18-30. [CrossRef]

51. Shtam, T.A.; Kovalev, R.A.; Varfolomeeva, E.Y.; Makarov, E.M.; Kil, Y.V.; Filatov, M.V. Exosomes are natural carriers of exogenous siRNA to human cells in vitro. Cell Commun. Signal. 2013, 11, 88. [CrossRef]

52. Pascucci, L.; Cocce, V.; Bonomi, A.; Ami, D.; Ceccarelli, P.; Ciusani, E.; Vigano, L.; Locatelli, A.; Sisto, F.; Doglia, S.M.; et al. Paclitaxel is incorporated by mesenchymal stromal cells and released in exosomes that inhibit in vitro tumor growth: A new approach for drug delivery. J. Control. Release 2014, 192, 262-270. [CrossRef] [PubMed]

53. Zhang, H.; Wang, Y.; Bai, M.; Wang, J.; Zhu, K.; Liu, R.; Ge, S.; Li, J.; Ning, T.; Deng, T.; et al. Exosomes serve as nanoparticles to suppress tumor growth and angiogenesis in gastric cancer by delivering hepatocyte growth factor siRNA. Cancer Sci. 2018, 109, 629-641. [CrossRef] [PubMed]

54. Silva, A.K.; Luciani, N.; Gazeau, F.; Aubertin, K.; Bonneau, S.; Chauvierre, C.; Letourneur, D.; Wilhelm, C. Combining magnetic nanoparticles with cell derived microvesicles for drug loading and targeting. Nanomedicine 2015, 11, 645-655. [CrossRef] [PubMed]

55. Di Bonito, P.; Chiozzini, C.; Arenaccio, C.; Anticoli, S.; Manfredi, F.; Olivetta, E.; Ferrantelli, F.; Falcone, E.; Ruggieri, A.; Federico, M. Antitumor HPV E7-specific CTL activity elicited by in vivo engineered exosomes produced through DNA inoculation. Int. J. Nanomed. 2017, 12, 4579-4591. [CrossRef] [PubMed] 
56. Zeelenberg, I.S.; Ostrowski, M.; Krumeich, S.; Bobrie, A.; Jancic, C.; Boissonnas, A.; Delcayre, A.; Le Pecq, J.B.; Combadiere, B.; Amigorena, S.; et al. Targeting tumor antigens to secreted membrane vesicles in vivo induces efficient antitumor immune responses. Cancer Res. 2008, 68, 1228-1235. [CrossRef] [PubMed]

57. De Gassart, A.; Trentin, B.; Martin, M.; Hocquellet, A.; Bette-Bobillo, P.; Mamoun, R.; Vidal, M. Exosomal sorting of the cytoplasmic domain of bovine leukemia virus TM Env protein. Cell Biol. Int. 2009, 33, 36-48. [CrossRef] [PubMed]

58. Yim, N.; Ryu, S.W.; Choi, K.; Lee, K.R.; Lee, S.; Choi, H.; Kim, J.; Shaker, M.R.; Sun, W.; Park, J.H.; et al. Exosome engineering for efficient intracellular delivery of soluble proteins using optically reversible protein-protein interaction module. Nat. Commun 2016, 7, 12277. [CrossRef]

59. Batagov, A.O.; Kuznetsov, V.A.; Kurochkin, I.V. Identification of nucleotide patterns enriched in secreted RNAs as putative cis-acting elements targeting them to exosome nano-vesicles. BMC Genomics 2011, 12 (Suppl. 3), S18. [CrossRef]

60. Teng, Y.; Ren, Y.; Hu, X.; Mu, J.; Samykutty, A.; Zhuang, X.; Deng, Z.; Kumar, A.; Zhang, L.; Merchant, M.L.; et al. MVP-mediated exosomal sorting of miR-193a promotes colon cancer progression. Nat. Commun. 2017, 8, 14448. [CrossRef]

61. Gibbings, D.J.; Ciaudo, C.; Erhardt, M.; Voinnet, O. Multivesicular bodies associate with components of miRNA effector complexes and modulate miRNA activity. Nat. Cell Biol. 2009, 11, 1143-1149. [CrossRef] [PubMed]

62. Blomme, A.; Fahmy, K.; Peulen, O.; Costanza, B.; Fontaine, M.; Struman, I.; Baiwir, D.; de Pauw, E.; Thiry, M.; Bellahcene, A.; et al. Myoferlin is a novel exosomal protein and functional regulator of cancer-derived exosomes. Oncotarget 2016, 7, 83669-83683. [CrossRef] [PubMed]

63. Hadla, M.; Palazzolo, S.; Corona, G.; Caligiuri, I.; Canzonieri, V.; Toffoli, G.; Rizzolio, F. Exosomes increase the therapeutic index of doxorubicin in breast and ovarian cancer mouse models. Nanomedicine 2016, 11, 2431-2441. [CrossRef] [PubMed]

64. Blanchard, N.; Lankar, D.; Faure, F.; Regnault, A.; Dumont, C.; Raposo, G.; Hivroz, C. TCR activation of human T cells induces the production of exosomes bearing the TCR/CD3/zeta complex. J. Immunol. 2002, 168, 3235-3241. [CrossRef] [PubMed]

65. Lamichhane, T.N.; Jeyaram, A.; Patel, D.B.; Parajuli, B.; Livingston, N.K.; Arumugasaamy, N.; Schardt, J.S.; Jay, S.M. Oncogene Knockdown via Active Loading of Small RNAs into Extracellular Vesicles by Sonication. Cell Mol. Bioeng. 2016, 9, 315-324. [CrossRef] [PubMed]

66. Sato, Y.T.; Umezaki, K.; Sawada, S.; Mukai, S.A.; Sasaki, Y.; Harada, N.; Shiku, H.; Akiyoshi, K. Engineering hybrid exosomes by membrane fusion with liposomes. Sci. Rep. 2016, 6, 21933. [CrossRef]

67. Yerneni, S.S.; Lathwal, S.; Shrestha, P.; Shirwan, H.; Matyjaszewski, K.; Weiss, L.; Yolcu, E.S.; Campbell, P.G.; Das, S.R. Rapid On-Demand Extracellular Vesicle Augmentation with Versatile Oligonucleotide Tethers. ACS Nano 2019, 13, 10555-10565. [CrossRef]

68. Martinelli, C.; Gabriele, F.; Dini, E.; Carriero, F.; Bresciani, G.; Slivinschi, B.; Dei Giudici, M.; Zanoletti, L.; Manai, F.; Paolillo, M.; et al. Development of Artificial Plasma Membranes Derived Nanovesicles Suitable for Drugs Encapsulation. Cells 2020, 9 , 1626. [CrossRef]

69. Nasiri Kenari, A.; Cheng, L.; Hill, A.F. Methods for loading therapeutics into extracellular vesicles and generating extracellular vesicles mimetic-nanovesicles. Methods 2020, 177, 103-113. [CrossRef]

70. Kalimuthu, S.; Gangadaran, P.; Rajendran, R.L.; Zhu, L.; Oh, J.M.; Lee, H.W.; Gopal, A.; Baek, S.H.; Jeong, S.Y.; Lee, S.W.; et al. A New Approach for Loading Anticancer Drugs into Mesenchymal Stem Cell-Derived Exosome Mimetics for Cancer Therapy. Front. Pharmacol. 2018, 9, 1116. [CrossRef]

71. Nasiri Kenari, A.; Kastaniegaard, K.; Greening, D.W.; Shambrook, M.; Stensballe, A.; Cheng, L.; Hill, A.F. Proteomic and PostTranslational Modification Profiling of Exosome-Mimetic Nanovesicles Compared to Exosomes. Proteomics 2019, 19, e1800161. [CrossRef] [PubMed]

72. Yang, Y.; Hong, Y.; Cho, E.; Kim, G.B.; Kim, I.S. Extracellular vesicles as a platform for membrane-associated therapeutic protein delivery. J. Extracell. Vesicles 2018, 7, 1440131. [CrossRef] [PubMed]

73. Bellavia, D.; Raimondo, S.; Calabrese, G.; Forte, S.; Cristaldi, M.; Patinella, A.; Memeo, L.; Manno, M.; Raccosta, S.; Diana, P.; et al. Interleukin 3- receptor targeted exosomes inhibit in vitro and in vivo Chronic Myelogenous Leukemia cell growth. Theranostics 2017, 7, 1333-1345. [CrossRef] [PubMed]

74. Alvarez-Erviti, L.; Seow, Y.; Yin, H.; Betts, C.; Lakhal, S.; Wood, M.J. Delivery of siRNA to the mouse brain by systemic injection of targeted exosomes. Nat. Biotechnol. 2011, 29, 341-345. [CrossRef] [PubMed]

75. Koh, E.; Lee, E.J.; Nam, G.H.; Hong, Y.; Cho, E.; Yang, Y.; Kim, I.S. Exosome-SIRPalpha, a CD47 blockade increases cancer cell phagocytosis. Biomaterials 2017, 121, 121-129. [CrossRef] [PubMed]

76. Kamerkar, S.; LeBleu, V.S.; Sugimoto, H.; Yang, S.; Ruivo, C.F.; Melo, S.A.; Lee, J.J.; Kalluri, R. Exosomes facilitate therapeutic targeting of oncogenic KRAS in pancreatic cancer. Nature 2017, 546, 498-503. [CrossRef]

77. Choi, E.S.; Song, J.; Kang, Y.Y.; Mok, H. Mannose-Modified Serum Exosomes for the Elevated Uptake to Murine Dendritic Cells and Lymphatic Accumulation. Macromol. Biosci. 2019, 19, e1900042. [CrossRef]

78. Kim, M.S.; Haney, M.J.; Zhao, Y.; Yuan, D.; Deygen, I.; Klyachko, N.L.; Kabanov, A.V.; Batrakova, E.V. Engineering macrophagederived exosomes for targeted paclitaxel delivery to pulmonary metastases: In vitro and in vivo evaluations. Nanomedicine 2018, 14, 195-204. [CrossRef]

79. Lloret-Llinares, M.; Karadoulama, E.; Chen, Y.; Wojenski, L.A.; Villafano, G.J.; Bornholdt, J.; Andersson, R.; Core, L.; Sandelin, A.; Jensen, T.H. The RNA exosome contributes to gene expression regulation during stem cell differentiation. Nucleic Acids Res. 2018, 46, 11502-11513. [CrossRef] 
80. Gu, X.; Erb, U.; Buchler, M.W.; Zoller, M. Improved vaccine efficacy of tumor exosome compared to tumor lysate loaded dendritic cells in mice. Int. J. Cancer 2015, 136, E74-E84. [CrossRef]

81. Sun, Y.; Liu, J. Potential of cancer cell-derived exosomes in clinical application: A review of recent research advances. Clin. Ther. 2014, 36, 863-872. [CrossRef] [PubMed]

82. Rong, L.; Li, R.; Li, S.; Luo, R. Immunosuppression of breast cancer cells mediated by transforming growth factor-beta in exosomes from cancer cells. Oncol. Lett. 2016, 11, 500-504. [CrossRef] [PubMed]

83. Wang, X.; Zhang, H.; Yang, H.; Bai, M.; Ning, T.; Deng, T.; Liu, R.; Fan, Q.; Zhu, K.; Li, J.; et al. Exosome-delivered circRNA promotes glycolysis to induce chemoresistance through the miR-122-PKM2 axis in colorectal cancer. Mol. Oncol. 2020, 14, 539-555. [CrossRef] [PubMed]

84. Lee, J.K.; Park, S.R.; Jung, B.K.; Jeon, Y.K.; Lee, Y.S.; Kim, M.K.; Kim, Y.G.; Jang, J.Y.; Kim, C.W. Exosomes derived from mesenchymal stem cells suppress angiogenesis by down-regulating VEGF expression in breast cancer cells. PLoS ONE 2013, 8, e84256. [CrossRef]

85. Pakravan, K.; Babashah, S.; Sadeghizadeh, M.; Mowla, S.J.; Mossahebi-Mohammadi, M.; Ataei, F.; Dana, N.; Javan, M. MicroRNA100 shuttled by mesenchymal stem cell-derived exosomes suppresses in vitro angiogenesis through modulating the mTOR/HIF1alpha/VEGF signaling axis in breast cancer cells. Cell. Oncol. 2017, 40, 457-470. [CrossRef]

86. Reza, A.; Choi, Y.J.; Yasuda, H.; Kim, J.H. Human adipose mesenchymal stem cell-derived exosomal-miRNAs are critical factors for inducing anti-proliferation signalling to A2780 and SKOV-3 ovarian cancer cells. Sci. Rep. 2016, 6, 38498. [CrossRef]

87. Viaud, S.; Terme, M.; Flament, C.; Taieb, J.; Andre, F.; Novault, S.; Escudier, B.; Robert, C.; Caillat-Zucman, S.; Tursz, T.; et al. Dendritic cell-derived exosomes promote natural killer cell activation and proliferation: A role for NKG2D ligands and IL15Ralpha. PLoS ONE 2009, 4, e4942. [CrossRef]

88. Simhadri, V.R.; Reiners, K.S.; Hansen, H.P.; Topolar, D.; Simhadri, V.L.; Nohroudi, K.; Kufer, T.A.; Engert, A.; Pogge von Strandmann, E. Dendritic cells release HLA-B-associated transcript-3 positive exosomes to regulate natural killer function. PLOS ONE 2008, 3, e3377. [CrossRef]

89. Munich, S.; Sobo-Vujanovic, A.; Buchser, W.J.; Beer-Stolz, D.; Vujanovic, N.L. Dendritic cell exosomes directly kill tumor cells and activate natural killer cells via TNF superfamily ligands. Oncoimmunology 2012, 1, 1074-1083. [CrossRef]

90. Besse, B.; Charrier, M.; Lapierre, V.; Dansin, E.; Lantz, O.; Planchard, D.; Le Chevalier, T.; Livartoski, A.; Barlesi, F.; Laplanche, A.; et al. Dendritic cell-derived exosomes as maintenance immunotherapy after first line chemotherapy in NSCLC. Oncoimmunology 2016, 5, e1071008. [CrossRef]

91. Gehrmann, U.; Hiltbrunner, S.; Georgoudaki, A.M.; Karlsson, M.C.; Naslund, T.I.; Gabrielsson, S. Synergistic induction of adaptive antitumor immunity by codelivery of antigen with alpha-galactosylceramide on exosomes. Cancer Res. 2013, 73, 3865-3876. [CrossRef]

92. Damo, M.; Wilson, D.S.; Simeoni, E.; Hubbell, J.A. TLR-3 stimulation improves anti-tumor immunity elicited by dendritic cell exosome-based vaccines in a murine model of melanoma. Sci. Rep. 2015, 5, 17622. [CrossRef]

93. Lu, Z.; Zuo, B.; Jing, R.; Gao, X.; Rao, Q.; Liu, Z.; Qi, H.; Guo, H.; Yin, H. Dendritic cell-derived exosomes elicit tumor regression in autochthonous hepatocellular carcinoma mouse models. J. Hepatol. 2017, 67, 739-748. [CrossRef]

94. Zhu, L.; Kalimuthu, S.; Gangadaran, P.; Oh, J.M.; Lee, H.W.; Baek, S.H.; Jeong, S.Y.; Lee, S.W.; Lee, J.; Ahn, B.C. Exosomes Derived from Natural Killer Cells Exert Therapeutic Effect in Melanoma. Theranostics 2017, 7, 2732-2745. [CrossRef]

95. Zhu, L.; Oh, J.M.; Gangadaran, P.; Kalimuthu, S.; Baek, S.H.; Jeong, S.Y.; Lee, S.W.; Lee, J.; Ahn, B.C. Targeting and Therapy of Glioblastoma in a Mouse Model Using Exosomes Derived from Natural Killer Cells. Front. Immunol. 2018, 9, 824. [CrossRef]

96. Jong, A.Y.; Wu, C.H.; Li, J.; Sun, J.; Fabbri, M.; Wayne, A.S.; Seeger, R.C. Large-scale isolation and cytotoxicity of extracellular vesicles derived from activated human natural killer cells. J. Extracell Vesicles 2017, 6, 1294368. [CrossRef]

97. Seo, N.; Shirakura, Y.; Tahara, Y.; Momose, F.; Harada, N.; Ikeda, H.; Akiyoshi, K.; Shiku, H. Activated CD8(+) T cell extracellular vesicles prevent tumour progression by targeting of lesional mesenchymal cells. Nat. Commun. 2018, 9, 435. [CrossRef]

98. Cheng, L.; Wang, Y.; Huang, L. Exosomes from M1-Polarized Macrophages Potentiate the Cancer Vaccine by Creating a Pro-inflammatory Microenvironment in the Lymph Node. Mol. Ther. 2017, 25, 1665-1675. [CrossRef]

99. Choi, H.; Kim, Y.; Mirzaaghasi, A.; Heo, J.; Kim, Y.N.; Shin, J.H.; Kim, S.; Kim, N.H.; Cho, E.S.; In Yook, J.; et al. Exosome-based delivery of super-repressor IkappaBalpha relieves sepsis-associated organ damage and mortality. Sci. Adv. 2020, 6, eaaz6980. [CrossRef]

100. Hong, Y.; Nam, G.-H.; Koh, E.; Jeon, S.; Kim, G.B.; Jeong, C.; Kim, D.-H.; Yang, Y.; Kim, I.-S. Exosome as a Vehicle for Delivery of Membrane Protein Therapeutics, PH20, for Enhanced Tumor Penetration and Antitumor Efficacy. Adv. Funct. Mater. 2018, 28, 1703074. [CrossRef]

101. Schindler, C.; Collinson, A.; Matthews, C.; Pointon, A.; Jenkinson, L.; Minter, R.R.; Vaughan, T.J.; Tigue, N.J. Exosomal delivery of doxorubicin enables rapid cell entry and enhanced in vitro potency. PLoS ONE 2019, 14, e0214545. [CrossRef]

102. Jeong, K.; Yu, Y.J.; You, J.Y.; Rhee, W.J.; Kim, J.A. Exosome-mediated microRNA-497 delivery for anti-cancer therapy in a microfluidic 3D lung cancer model. Lab. Chip. 2020, 20, 548-557. [CrossRef]

103. Wang, J.; Wu, Y.; Guo, J.; Fei, X.; Yu, L.; Ma, S. Adipocyte-derived exosomes promote lung cancer metastasis by increasing MMP9 activity via transferring MMP3 to lung cancer cells. Oncotarget 2017, 8, 81880-81891. [CrossRef] 
104. Lazar, I.; Clement, E.; Dauvillier, S.; Milhas, D.; Ducoux-Petit, M.; LeGonidec, S.; Moro, C.; Soldan, V.; Dalle, S.; Balor, S.; et al. Adipocyte Exosomes Promote Melanoma Aggressiveness through Fatty Acid Oxidation: A Novel Mechanism Linking Obesity and Cancer. Cancer Res. 2016, 76, 4051-4057. [CrossRef]

105. Crapnell, K.; Blaesius, R.; Hastings, A.; Lennon, D.P.; Caplan, A.I.; Bruder, S.P. Growth, differentiation capacity, and function of mesenchymal stem cells expanded in serum-free medium developed via combinatorial screening. Exp. Cell Res. 2013, 319, 1409-1418. [CrossRef]

106. Shojaei, S.; Hashemi, S.M.; Ghanbarian, H.; Salehi, M.; Mohammadi-Yeganeh, S. Effect of mesenchymal stem cells-derived exosomes on tumor microenvironment: Tumor progression versus tumor suppression. J. Cell. Physiol. 2019, 234, 3394-3409. [CrossRef]

107. Wen, C.; Seeger, R.C.; Fabbri, M.; Wang, L.; Wayne, A.S.; Jong, A.Y. Biological roles and potential applications of immune cell-derived extracellular vesicles. J. Extracell. Vesicles 2017, 6, 1400370. [CrossRef]

108. Lindenbergh, M.F.S.; Stoorvogel, W. Antigen Presentation by Extracellular Vesicles from Professional Antigen-Presenting Cells. Annu. Rev. Immunol. 2018, 36, 435-459. [CrossRef]

109. Ewen, C.L.; Kane, K.P.; Bleackley, R.C. A quarter century of granzymes. Cell Death Differ. 2012, 19, 28-35. [CrossRef]

110. Kaspar, A.A.; Okada, S.; Kumar, J.; Poulain, F.R.; Drouvalakis, K.A.; Kelekar, A.; Hanson, D.A.; Kluck, R.M.; Hitoshi, Y.; Johnson, D.E.; et al. A distinct pathway of cell-mediated apoptosis initiated by granulysin. J. Immunol. 2001, 167, 350-356. [CrossRef]

111. Keefe, D.; Shi, L.; Feske, S.; Massol, R.; Navarro, F.; Kirchhausen, T.; Lieberman, J. Perforin triggers a plasma membrane-repair response that facilitates CTL induction of apoptosis. Immunity 2005, 23, 249-262. [CrossRef] [PubMed]

112. Burgents, J.E.; Moran, T.P.; West, M.L.; Davis, N.L.; Johnston, R.E.; Serody, J.S. The immunosuppressive tumor environment is the major impediment to successful therapeutic vaccination in Neu transgenic mice. J. Immunother. 2010, 33, 482-491. [CrossRef] [PubMed]

113. Gyorgy, B.; Hung, M.E.; Breakefield, X.O.; Leonard, J.N. Therapeutic applications of extracellular vesicles: Clinical promise and open questions. Annu. Rev. Pharmacol. Toxicol. 2015, 55, 439-464. [CrossRef] [PubMed]

114. Garzetti, L.; Menon, R.; Finardi, A.; Bergami, A.; Sica, A.; Martino, G.; Comi, G.; Verderio, C.; Farina, C.; Furlan, R. Activated macrophages release microvesicles containing polarized M1 or M2 mRNAs. J. Leukoc. Biol. 2014, 95, 817-825. [CrossRef]

115. Charoenviriyakul, C.; Takahashi, Y.; Morishita, M.; Matsumoto, A.; Nishikawa, M.; Takakura, Y. Cell type-specific and common characteristics of exosomes derived from mouse cell lines: Yield, physicochemical properties, and pharmacokinetics. Eur. J. Pharm. Sci. 2017, 96, 316-322. [CrossRef]

116. Willis, G.R.; Kourembanas, S.; Mitsialis, S.A. Toward Exosome-Based Therapeutics: Isolation, Heterogeneity, and Fit-for-Purpose Potency. Front. Cardiovasc. Med. 2017, 4, 63. [CrossRef]

117. Yamashita, T.; Takahashi, Y.; Nishikawa, M.; Takakura, Y. Effect of exosome isolation methods on physicochemical properties of exosomes and clearance of exosomes from the blood circulation. Eur. J. Pharm. Biopharm. 2016, 98, 1-8. [CrossRef]

118. Franzen, C.A.; Simms, P.E.; Van Huis, A.F.; Foreman, K.E.; Kuo, P.C.; Gupta, G.N. Characterization of uptake and internalization of exosomes by bladder cancer cells. Biomed. Res. Int. 2014, 2014, 619829. [CrossRef]

119. Watson, D.C.; Bayik, D.; Srivatsan, A.; Bergamaschi, C.; Valentin, A.; Niu, G.; Bear, J.; Monninger, M.; Sun, M.; Morales-Kastresana, A.; et al. Efficient production and enhanced tumor delivery of engineered extracellular vesicles. Biomaterials 2016, 105, 195-205. [CrossRef]

120. Harmati, M.; Tarnai, Z.; Decsi, G.; Kormondi, S.; Szegletes, Z.; Janovak, L.; Dekany, I.; Saydam, O.; Gyukity-Sebestyen, E.; Dobra, G.; et al. Stressors alter intercellular communication and exosome profile of nasopharyngeal carcinoma cells. J. Oral. Pathol. Med. 2017, 46, 259-266. [CrossRef]

121. Kanemoto, S.; Nitani, R.; Murakami, T.; Kaneko, M.; Asada, R.; Matsuhisa, K.; Saito, A.; Imaizumi, K. Multivesicular body formation enhancement and exosome release during endoplasmic reticulum stress. Biochem. Biophys. Res. Commun. 2016, 480 , 166-172. [CrossRef] [PubMed]

122. King, H.W.; Michael, M.Z.; Gleadle, J.M. Hypoxic enhancement of exosome release by breast cancer cells. BMC Cancer 2012, 12, 421. [CrossRef]

123. Ferguson, S.W.; Nguyen, J. Exosomes as therapeutics: The implications of molecular composition and exosomal heterogeneity. J. Control. Release 2016, 228, 179-190. [CrossRef] [PubMed]

124. Zhang, J.; Li, S.; Li, L.; Li, M.; Guo, C.; Yao, J.; Mi, S. Exosome and exosomal microRNA: Trafficking, sorting, and function. Genom. Proteom. Bioinform. 2015, 13, 17-24. [CrossRef]

125. Villarroya-Beltri, C.; Baixauli, F.; Gutierrez-Vazquez, C.; Sanchez-Madrid, F.; Mittelbrunn, M. Sorting it out: Regulation of exosome loading. Semin. Cancer Biol. 2014, 28, 3-13. [CrossRef]

126. Willms, E.; Johansson, H.J.; Mager, I.; Lee, Y.; Blomberg, K.E.; Sadik, M.; Alaarg, A.; Smith, C.I.; Lehtio, J.; El Andaloussi, S.; et al. Cells release subpopulations of exosomes with distinct molecular and biological properties. Sci. Rep. 2016, 6, 22519. [CrossRef]

127. Chiang, C.Y.; Chen, C. Toward characterizing extracellular vesicles at a single-particle level. J. Biomed. Sci. 2019, 26, 9. [CrossRef]

128. Corso, G.; Heusermann, W.; Trojer, D.; Gorgens, A.; Steib, E.; Voshol, J.; Graff, A.; Genoud, C.; Lee, Y.; Hean, J.; et al. Systematic characterization of extracellular vesicle sorting domains and quantification at the single molecule-single vesicle level by fluorescence correlation spectroscopy and single particle imaging. J. Extracell. Vesicles 2019, 8, 1663043. [CrossRef]

129. Lee, K.; Fraser, K.; Ghaddar, B.; Yang, K.; Kim, E.; Balaj, L.; Chiocca, E.A.; Breakefield, X.O.; Lee, H.; Weissleder, R. Multiplexed Profiling of Single Extracellular Vesicles. ACS Nano 2018, 12, 494-503. [CrossRef] 
130. Escudier, B.; Dorval, T.; Chaput, N.; Andre, F.; Caby, M.P.; Novault, S.; Flament, C.; Leboulaire, C.; Borg, C.; Amigorena, S.; et al. Vaccination of metastatic melanoma patients with autologous dendritic cell (DC) derived-exosomes: Results of thefirst phase I clinical trial. J. Transl. Med. 2005, 3, 10. [CrossRef]

131. Morse, M.A.; Garst, J.; Osada, T.; Khan, S.; Hobeika, A.; Clay, T.M.; Valente, N.; Shreeniwas, R.; Sutton, M.A.; Delcayre, A.; et al. A phase I study of dexosome immunotherapy in patients with advanced non-small cell lung cancer. J. Transl. Med. $2005,3,9$. [CrossRef] [PubMed]

132. Dai, S.; Wei, D.; Wu, Z.; Zhou, X.; Wei, X.; Huang, H.; Li, G. Phase I clinical trial of autologous ascites-derived exosomes combined with GM-CSF for colorectal cancer. Mol. Ther. 2008, 16, 782-790. [CrossRef] [PubMed] 